\title{
STRATEGI POLITIK HIZBUT TAHRIR DALAM MENEGAKKAN KHILAFAH ISLAM DI INDONESIA
}

\author{
${ }^{1}$ HASANUDDIN, ${ }^{2}$ EDI SABARA MANIK, \\ ${ }^{1,2}$ Program Pascasarjana IImu Politik, Universitas Riau \\ Pembebas_sejati@yahoo.co.id
}

\begin{abstract}
Hizb ut-Tahrir Indonesia ( $\mathrm{HTI})$ is an Islamic organization that became famous and became the subject of discussion after being dissolved by the Indonesian government through PERPPU no. 2 Year 2017. Many different views on the struggle Hizbut Tahrir Indonesia. The Indonesian government considers that the activities and ideas undertaken by HTI can divide the Unitary Republic of Indonesia (NKRI). However, some national figures assume that HTl's struggle is not contradictory to the constitution and the idea conveyed by HTI namely the Khilafah is part of the teachings of Islam. In this paper, the author examines how HTI embodies the idea of the Khilafah. From the results of the study can be concluded that there are three strategies undertaken in realizing the Khilafah is first, the stage of coaching and cadre (tatsqif); second, interaction and struggle (marhalah tafaul wal kifah); third, the acceptance of power and application of law by the state (Marhalah tathbiq ahkamul Islam).
\end{abstract}

Kata Kunci : Hizbut Tahrir, HTI, Khilafah, Strategi

\section{A. Pendahuluan}

Hizbut Tahrir Indonesia adalah ormas Islam yang telah dibubarkan oleh pemerintah Indonesia melalui Peraturan Pemerintah No. 2 tahun 2017. Dalam satu tahun terakhir, ormas Islam ini menjadi viral diperbincangkan pasca pembubarannya. Banyak pengamat dan tokoh Negara yang angkat bicara dalam masalah pembubaran ormas islam ini.

Hizbut Tahrir (HT) merupakan gerakan Islam trans-nasional yang bergerak dalam dakwah dan politik. Didirikan oleh Syaikh Taqiyuddin alNabhani pada tahun 1953 di Palestina. Hizbut Tahrir (HT) seperti dikemukakan Whine (2006) berasal dari Bahasa Arab Hizb at-Tahrir yang 
berarti Partai Pembebasan (Party of Liberation) merupakan sebuah organisasi politik berideologi islam yang didirikan oleh Syeikh Taqiyuddin An-Nabhani pada tahun 1953 di Al-Quds, Baitul Maqdis, Palestina dengan tujuan untuk mendirikan Khilafah Islamiyah di muka bumi, yakni sistem pemerintahan berdasarkan syariat Islam. Hal ini dikarenakan HT melihat kondisi umat islam diseluruh dunia terus mengalami kemerosotan dan dikuasai oleh sistem ataupun tata kelola pemerintahan dari negara-negara liberalis dengan segala bentuk modernisasi yakni Barat. Selain Barat, HT juga mengambil posisi sebagai organisasi yang anti terhadap Zionisme dan tentunya Israel sebagai negara karena berkeyakinan kedua entitas ini sebagai sumber penderitaan utama masyarakat Palestina. Bahkan, jika dibandingkan dengan Ikhwanul Muslimin (IM), organisasi serupa yang didirikan Hassan AlBanna di Mesir tahun 1928, HT sebagaimana diuraikan MiltonEdwards (1996) menyatakan demikian. Tujuan utamanya adalah melangsungkan kembali kehidupan Islam dan mengemban kembali dakwah Islam ke seluruh penjuru dunia, serta mengajak kaum muslim untuk kembali hidup secara islami dalam naungan khilāfah Islamiyah „alā minhāj al-nubuwwah. Untuk mencapai tujuan tersebut HT menerapkan langkah-langkah dakwahnya dalam tiga tahap: tatsqif (pembinaan dan pengkaderan), tafa"ul (interaksi) dengan umat, dan istilām al-hukmi (menerima kekuasaan) dari umat (Mohammadin, 2016). Di Indonesia HT mendeklarasikan diri dengan nama HizbutTahrir Indonesia (HTI). Masuk pertama kali pada tahun 1980-an di bawah pimpinan Abd. Rahman al-aghdadi.(Mohamad, 2015)

Selanjutnya, melihat dari tujuan yang ingin dicapai oleh HT yakni mendirikan Khilafah Islamiyah di muka bumi berarti tujuan ini berlaku secara global. Posisi dan sikap yang diambil oleh HT ini dapat dikategorikan sebagai kelompok ekstremis jika merujuk pada fitur-fitur ekstremisme yang Hartleb (2012) antara lain: (1) dogmatis;(2) pola interaksi kawan-lawan; (3) ilusi mengenai harmonisasi dunia di masa depan; dan (4) memiliki sosok pemimpin atau panutan yang kharismatik.

Perkembangan HT sebagai organisasi politik berideologi Islam dengan misi global perlu dicermati sebagai isu internasional yang berpotensi mengancam stabilitas keamanan global. Dalam Baran (2004) disebutkan bahwa HT pada awal didirikanoleh Syekh Taqiuddin an-Nabhani cenderung menggunakan metode persuasif, jauh dari kekerasan apalagi tindakan terorisme untuk menjalankan misi utamanya, namun pada akhir 1980an struktur kepemimpinan HT yang beralih ke generasi muda merasa HT tidak progresif dalam upaya pencapaian misi utamanya yakni Khilafah Islamiyah.

Di sisi lain, secara komposisi metode dakwah HT lebih didominasi oleh tindakan-tindakan yang 
memang jauh dari kekerasan, terlebih tindakan terorisme. Namun hal yang perlu dicatat adalah bahwa ambisi HT untuk mendirikan Khilafah Islamiyah dalam skala global, ini berarti HT akan menyebarluaskan pengaruhnya keberbagai negara di seluruh dunia, dan berkat globalisasi hal ini dapat terjadi. HT sendiri hingga saat ini merupakan organisasi politik berideologi Islam yang memiliki cabang di beberapa negara di seluruh dunia antara lain Indonesia, Australia, Amerika Serikat, Bangladesh, Belanda, Inggris, Jerman, Denmark, Yordania, Mesir, Irak, Sudan, Tunisia, Aljazair, Uzbekistan, Kazakhstan, Kyrgystan, Swedia, Lebanon, dan masih banyak negara lain (Whine 2010).

Menurut Hilmy (2011), ideologi transnasionalisme HTI lebih merepresentasikan pergerakan "sentrifugalisme" Islam, di mana visi politiknya adalah menyatukan identitas-identitas Islam nasional dan local yang berserak di seluruh dunia di bawah otoritas tunggal Khilafah Islamiyah. Doktrin tersebut diakui oleh para aktivis $\mathrm{HTI}$ sebagai antitesis ideologis yang siap menandingi, bahkan mengganti, posisi konsep negara-bangsa (NKRI) yang sudah dianggap final di Indonesia. Dan dengan berkeyakinan pada pendirian khilafah yang dilandaskan kepada beberapa ayat al-Qur'an, HTI berusaha membangun negara khilafah dan penegak syariah yang lengkap dengan gagasan pemikiran yang mereka tuangkan dalam berbagai media baik cetak maupun elektronik dalam rangka mengkomunikasikan pesan mereka kepada khalayak (Nilda, 2017). Oleh sebab itu, menarik untuk dibahas bagaimana strategi HTI dalam menwujudkan Khilafah di Indonesia.

\section{B. NEGARA KHILAFAH MENURUT HIZBUT TAHRIR}

Kalangan sekularis sering mengemukakan argumentasi yang cukup analitis, dengan pernyataan bahwa al-Qur'an dan as-Sunnah tidak pernah menyinggung sedikit pun tentang daulah (negara). Para penganjur sekularisasi berpandangan bahwa di dalam Islam tidak pernah ada ajaran yang membahas masalah kenegaraan. Mendirikan daulah tidak ada pijakan nashnya. Bahkan, istilah daulah (negara) juga tidak ditemukan dalam al-Qur'an maupun as-Sunnah.

Untuk menjawab sikap kritis para penganjur sekularisasi, menurut penulis harus di kedepankan alasan-alasan argumentatif dan jernih. Penulis mencermati, pandangan sekularis ini tentu saja benar jika didasarkan pada pemahaman yang cenderung literalis. Pandangan tersebut harus diuji kebenarannya terlebih dahulu. Paling tidak diperlukan analisa yang intens dan terukur.

Yusuf as-Sabatin berpendapat, bahwa mungkin karena kata state mempunyai ciri-ciri pembagian kerja, kekuasaan politik, penguasa, dan sebagainya, kata tersebut kemudian diterjemahkan dengan kata daulah, yang mempunyai ciri-ciri al-uqbah (pergiliran) dan al-ghalabah (kemenangan atau kekuasaan), seperti yang dinyatakan di atas. 
Dengan demikian, kata daulah (negara) bukan merupakan kata yang dinyatakan oleh nash, baik alQur'an maupun as-Sunnah. Sebab itu, untuk mendefiniskannya tidak bisa menggunakan kedua nash tersebut, kecuali dengan berpedoman pada realitas bahwa negara merupakan kumpulan manusia, atau dengan melihat realitas manusia dengan berbagai cirinya. Manusia adalah makhluk yang diberi akal oleh Allah. Sebab itu, ia mampu melahirkan dan memahami pemikiran. Pemikiran dalam diri manusia sangat penting karena pemikiranlah yang mengendalikan perasaan dan tingkah lakunya dalam kehidupan.

Dalam pandangan Yusuf asSabatin, sebuah negara berdasarkan realitas negara sebagai entitas dan struktur kekuasaan serta akumulasi manusia yang mempunyai pemikiran. Definisi ini boleh digunakan secara umum untuk semua negara; baik Kapitalis, Sosialis maupun Islam. Sifat Kapitalis, Sosialis dan Islam, baru ada jika masing-masing pemahaman, standarisasi, dan keyakinan negara tersebut adalah Kapitalis, Sosialis, atau Islam. Berdasarkan perbedaan pemahaman, standarisasi dan keyakinan inilah identitas sebuah negara bisa ditentukan.

Menurut Yusuf as-Sabatin, bahwa kata daulah memang tidak dinyatakan oleh al-Qur'an dan asSunnah atau nash syariat karena istilah ini memang merupakan istilah asing. Akan tetapi, tidak berarti bahwa penjelasan yang berkaitan dengan realitas negara tidak ada dalam al-Qur'an dan as-Sunnah. Ali Abdurraziq (1995) berpandangan bahwa Islam tidak membahas realitas tersebut.

Tuduhan tersebut jelas kontradiktif dengan nash al-Qur'an yang qathi'i, bahwa Islam adalah agama yang lengkap dan sempurna. Yang benar, realitas yang dimaksud oleh kata daulah (negara) tersebut telah dijelaskan oleh Islam, tetapi dengan menggunakan istilah yang khas, yaitu al-khilafah. Kata alkhilafah ini terdapat antara lain, dalam hadis hasan riwayat al-bazzar

Rasulullah bersabda :

Artinya; Sesungguhnya (urusan) agama kalian berawal dengan kenabian dan rahmat, kemudian akan ada khilafah dan rahmat, kemudian akan ada kekuasaan dan kesengsaraan (jabariyyah). (HR. al-Bazzar).

Kata khilafah dalam hadis di atas mempunyai konotasi sistem pemerintah yang merupakan pewaris pemerintahan kenabian. Ini juga dijelaskan dalam hadis shahih riwayat Muslim yang menyatakan :

Artinya; Dulu bani Israel dipimpin dan diurus oleh para Nabi. Jika para nabi itu telah wafat, mereka digantikan oleh Nabi yang baru. Akan tetapi, setelahku tidak ada lagi seorang Nabi, dan akan ada khalifah yang banyak. (HR. Muslim).

Hadis yang kedua ini menjelaskan, bahwa fase pemerintahan yang pertama adalah 
fase pemerintahan dengan sistem kenabian, tetapi setelah tidak ada lagi nabi yang diutus, sistem kenabian tersebut diteruskan oleh para khalifah (bentuk pluralnya khulafa'), yaitu orang yang menduduki khilafah. Berdasarkan hadis di atas, dapat dipahami bahwa Nabi Saw mewarisi sistem pemerintahan untuk melaksanakan urusan umatnya adalah sistem khilafah. Jadi dalam hal ini, tugas Nabi Saw tersebut dalam urusan pemerintahan, bukan dalam urusan kenabian. Sebab, urusan kenabian adalah masalah pengangkatan dari Allah, sedangkan urusan pemerintahan adalah masalah pengangkatan manusia.

Realitas bahwa khilafah merupakan sistem pemerintahan yang diwariskan oleh Nabi Saw bisa dibuktikan melalui ungkapan hadis shahih riwayat Bukhari dan Muslim di atas. Dalam hadis tersebut disebutkan "Kaanat bani Isra'il tasusuhum al-anbiya" (Dulu bani Israel dipimpin dan diurus oleh para Nabi). Kata tasusuhum al-anbiya' (dipimpin dan diurus oleh para Nabi) menunjukkan bahwa para Nabi tersebut memegang jabatan politis (siyasah) seperti yang dipegang oleh Daud a.s. dan Sulaiman a.s. Keduanya tidak hanya menjadi Nabi, tetapi juga memegang jabatan pemerintahan. Ketika sampai kepada Muhammad Saw, Rasulullah bersabda : Kullama halaka nabi khalafahu nabi wa innahu la nabiya ba'di (Ketika para Nabi itu telah wafat, mereka digantikan oleh Nabi yang baru. setelahku tidak ada lagi seorang Nabi).
Dari paparan tersebut dapat dipahami bahwa Nabi Saw merupakan pengganti para Nabi sebelumnya dalam urusan politik (siyasah) di samping pengganti dalam urusan kenabian. Ini yang ditunjukkan dalam sirah Nabi Saw mulai dari mendirikan partai; mengambil kekuasaan untuk menerapkan Islam di Madinah; membuat perjanjian dengan Yahudi dan Quraisy; melalukan seri peperangan; dan sebagainya.

Semua ini, menurut Ibnu Khaldun merupakan aktivitas politik, sementara aktivitas kenabian dinyatakan oleh al-Qur'an sebagai aktivitas tabligh (penyampaian risalah) (Ibnu Khaldun,2001). Dengan demikian, dapat disimpulkan bahwa realitas yang dimaksud oleh kata daulah (bahasa Arab) atau state (bahasa Inggris) tersebut dibahas oleh Islam dalam sebuah wacana yang khas, yang disebut oleh nash syariat dengan istilah alkhilafah. Ibnu Khaldun juga menggunakan kata daulah Islamiyah (negara Islam); kata daulah (negara) disertai ajektif Islamiyah (Islam) untuk menyebut al-khilafah. Memang, Ibn Khaldun bukan merupakan intelektual muslim yang pertama menggunakan perkataan daulah Islamiyyah untuk menyebut al-khilafah. la tetap menggunakan kata al-khilafah ini (Ibnu Khaldun,2001).

Dalam konteks ini, Ibn Khaldun memberikan sifat Islamiyah pada kata daulah karena kata tersebut bermakna umum; meliputi Islam dan non Islam. Ibnu Khaldun membedakan siyasah 'aqliyah 
(politik dan pemerintahan akal) dengan siyasah syariyah (politik dan pemerintahan syariat). Dikatakan siyasah 'aqliyah karena undangundang yang diterapkan oleh negara tersebut bersumber dari akal para tokoh pemikir negara. Sedangkan dikatakan siyasah syar'iyah karena undang-undang yang diterapkan oleh negara bersumber dari syariat Allah. Negara Islam masa Rasulullah disebut dengan al-mulk (kerajaan) atau daulah (negara), sedangkan negara Islam masa Ibnu Khaldun menyebut dengan al-khilafah atau ad-Daulah al-Islamiyah. (Abdul Qadim, 2002)

Berdasarkan paparan tersebut, istilah daulah Islamiyah (negara Islam) hanya mempunyai satu makna, yaitu al-khilafah, sesuai maksud yang dikehendaki oleh intelektual yang menggunakan istilah tersebut. Logika Ibn Khaldun ini menyimpulkan bahwa negara alQur'an dan as-Sunnah adalah alkhilafah, bukan yang lain. Pada dasarnya al-Qur'an dan as-Sunnah telah membahas konsep kenegaraan meskipun tidak menggunakan istilah daulahkarena kata ini merupakan istilah asingmelainkan dengan menggunakan istilah al-khilafah. Sama seperti ketika membahas aqidah; al-Qur'an maupun as-Sunnah tidak menggunakan istilah aqidah melainkan menggunakan istilah iman, tetapi dengan maksud yang sama.

Dari analisa peristilahan daulah (negara) tersebut, jelaslah bahwa kritikan para penganjur sekularisasi sangat tidak argumentatif dan irrasional. Menurut penulis, para pemikir politik Islam klasik seperti Ibnu Taimiyah, AlGhazali, Ibnu Khaldun dan lain-lain, maupun para pemikir politik Islam kontemporer, seperti Hasan alBanna, Sayyid Quthb, Taqiyuddin An-Nabhani, Muhammad Dhiauddin Rais, Yusuf Qardhawi dan lain-lain, telah memberikan pendapat sekaligus jawaban tentang eksistensi negara dan hukum mendirikannya. Meskipun para pemikir tersebut berbeda logika hukum tentang pembentukan negara, namun mereka sependapat mengenai hukum mendirikan negara adalah wajib.

Pemikir politik Islam klasik, Ibnu Taimiyah mengumpamakan agama dan negara merupakan dua saudara kembar yang satu sama lain tak dapat dipisahkan. Negara tanpa agama adalah berbahaya, sebaliknya agama tanpa negara tak dapat terlaksana dengan sempurna. Menurut Ibnu Taimiyah bahwa negara yang tanpa agama, akan jadi tirani (Ibnu Khaldun,2001). Menurut Ibnu Taimiyah bahwa agama tanpa sulthan, jihad dan mal, adalah seburuk sulthan dan harb artinya sesuatu yang paling buruk. Mengatur masalah manusia adalah kewajiban agama. Menurut Ibn Taimiyah, kebutuhan manusia tidak akan terpenuhi jika tidak ada kerjasama antar masyarakat di bawah bimbingan negara.

Ibnu Taimiyah menyatakan, bahwa imam atau kepala negara merupakan jantung sebuah negara. la mengibaratkan negara itu laksana satu tubuh. Ibnu Taimiyah melihat 
bahwa kehidupan agama tidak terlepas dari kehidupan kenegaraan. Dengan ini pula bahwa berpolitik dan beragama tidak dapat dipisahkan. Tugas khalifah adalah mewujudkan syariat Islam dan melindungi manusia dari perbuatan bid'ah yang merusak manusia (I.J. Rosenthal, 1965).

Menurut Ibnu Taimiyah bahwa wajib diketahui kekuasaan untuk mengatur urusan manusia (wilayah amr an-nash) termasuk salah satu kewajiban agama terbesar. Bahkan tanpa kekuasaan, urusan agama dan dunia tidak akan bisa ditegakkan. Kemaslahatan manusia tidak akan sempurna kecuali dengan adanya interaksi di antara mereka karena adanya kebutuhan satu sama lain. Sementara itu, interaksi di antara mereka mengharuskan adanya seorang pemimpin. Rasulullah bersabda :

Artinya; Jika ada tiga orang keluar untuk melakukan suatu perjalanan, hendaklah salah seorang di antara mereka menjadi pemimpinnya. (HR. Abu Daud).

Dengan demikian, menurut Ibnu Taimiyah, bahwa Nabi Muhammad telah mewajibkan kaum muslimin untuk mengangkat seorang pemimpin, meskipun dalam kelompok yang kecil di dalam suatu perjalanan. la menjelaskan bahwa perintah Nabi Muhammad ini merupakan isyarat bahwa kaum muslimin wajib mengangkat seorang pemimpin.(Ibnu Taimiyah, 2005)

Seirama dengan pandangan tersebut, politik (siyasah) menurut alGhazali, jauh lebih luas maknanya dari pada makna politik dalam pengertian yang populer sekarang. Segala hal, seperti memperbaiki kehidupan makhluk Tuhan dan menujukkan ke jalan yang benar, yang menyelamatkan mereka di dunia dan akhirat, termasuk politik. Berbicara mengenai hukum mendirikan negara (khilafah), alGhazali berpendapat bahwa hukum mendirikannya itu adalah wajib syar'i. la menegaskan bahwa hukumnya wajib kifayah. Alasan AlGhazali bahwa wajibnya itu karena ijma' (Al-Ghazali,1937). Berkenaan dengan pandangan Al-Ghazali tersebut, Muhammad Din Syamsuddin mengemukakan bahwa Al-Gazali memahami khilafah bukan hanya tuntutan yang didasarkan atas wahyu sebagaimana dikemukakan para fuqaha, tapi juga atas pertimbangan rasional, dalam arti falsafi. (Muhammad,2001)

Menurut Al-Ghazali bahwa dasar hukum wajib mendirikan khilafah itu adalah sejarah umat Islam itu sendiri, yakni kesepakatan (ijma) sahabat yang mengangkat Abu Bakar sebagai pengganti Rasulullah. Ini berarti bahwa selain mendirikan khilafah suatu kewajiban, di samping itu pula merupakan kontinuitas historis yang didukung oleh kesadaran yang menyatu dengan masa lampau. Seakan tidak ada yang memisahkan antara dua masa tersebut. Tegasnya, eksistensi khilafah selain sebagai kewajiban, juga simbol kontinuitas historis. AlGhazali menegaskan bahwa hubungan antara agama dengan kekuasaan (pemerintahan) adalah dua saudara kembar. Agama 
menjadi dasar (asas) dan kekuasaan (pemerintahan) menjadi pemelihara. (Muhammad,2001)

Identik dengan pandangan tersebut, Ibnu Khaldun menyatakan bahwa pengangkatan kepala negara dan pembentukan lembaga-lembaga negara adalah wajib syari. Artinya, kemestian adanya jabatan imam dan lembaga imamah itu ditunjuk oleh syariat, berdasarkan ijma' sahabat. Dalam hal ini, ia menentang pendapat mereka yang mengatakan bahwa kewajiban tersebut adalah berdasarkan wajib aqli, bukan syar'i.

Pembentukan negara (khilafah) dalam pandangan Ibnu Khaldun hukumnya wajib kifayah, sedangkan pengangkatan imam diserahkan kepada ahlul halli wal aqdi, yaitu golongan ulama dan umara'. Menurutnya, setiap orang wajib taat kepada imam. Allah berfirman :

$$
\begin{aligned}
& \text { بايهاالذين امنـوآ اطيعوا الله واطيعوا الرسـول واو }
\end{aligned}
$$

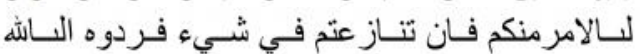

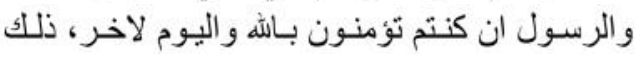

$$
\begin{aligned}
& \text { خير واحسن تأويلا . مترن }
\end{aligned}
$$

Artinya; Hai orang-orang yang beriman, taatilah Allah dan taati Rasul dan Pemimpin di antara kamu. Kemudian jika kamu berlainan pendapat tentang sesuatu, maka kembalikanlah ia kepada Allah dan Rasul (al-Qur'an dan asSunnah), jika kamu benarbenar beriman kepada Allah dan hari kemudian. Yang demikian itu lebih utama (bagimu) dan lebih baik akibatnya. (QS. An-Nisa : 59).
Ayat ini telah mewajibkan semua orang yang beriman agar taat kepada Allah dan Rasulnya serta Ulil Amri (Pemerintah), jika benar-benar orang itu beriman. (Ibnu Khaldun, 2001)

Dalam pandangan Ibnu Khaldun, bahwa pembentukan khilafah meriupakan kewajiban umat dan memerlukan konsensus umum (ijma) dari anggota umat yang kompeten. Tapi Ibnu Khaldun tidak mencari landasan ijma ini dalam syariah, melainkan dalam solidaritas kelompok. (Muhammad, 2001)

Pemikir politik Islam kontemporer cukup banyak yang membahas mengenai eksistensi negara dan kewajiban mendirikannya. Secara selektif, penulis hanya mengkedepankan dua nama saja yang mewakili pemikir politik kontemporer, yaitu Sayyid Qutub dan Taqiyuddin An-Nabhani. Menurut Sayyid Qutub, Islam merupakan agama yang realistik, yang membuktikan bahwa larangan dan nasihat saja tidak cukup. Juga membuktikan, bahwa agama ini tidak akan tegak tanpa negara dan kekuasaan. Agama adalah manhaj atau sistem yang menjadi dasar yang menjadi dasar kehidupan praktis manusia, bukan hanya sekedar perasaan emosional (wijdan) yang tersemat dalam hati, tanpa kekuasaan, perundangundangan, manhaj yang speksifik dan konstitusi yang jelas. Berbicara mengenai hukum mendirikan negara (khilafah), Sayyid Qutub mengemukakan bahwa hukum mendirikannya itu adalah wajib syar'i. la menegaskan bahwa 
hukumnya wajib kifayah. (Abdullah, 2000)

Sayyid Qutb memahami bahwa dalam negara Islam, hukum dan legalisasi yang sebenarnya hanya milik Allah, dan konsekuensinya syariah menjadi konstitusi fundamental. Pemahaman ini telah melahirkan teori Qutb bahwa kedaulatan Ilahiyah tertinggi atau Hakimiyah sebagai hasil interpretasi tekstual dari ayat-ayat alQur'an: "siapa saja yang memerintah tidak sesuai dengan wahyu Allah adalah kafir, fasik dan munafik". (QS. 5:34,35,36). Dalam sinaran teori ini, hukum Ilahiah (Islami) adalah sangat komprehensif dan terhindar dari berbagai aturan dan otoritas manusia. Beberapa otoritas non Ilahiah adalah thagut, yang tidak memiliki legitimasi, tidak religius, dan tiran. (Muhammad, 2001)

Dalam konsepsinya tentang negara Islam, Sayyid Qutb menekankan pentingnya dimensi sosial, ekonomi dan politik. la menegaskan bahwa negara Islam akan menjamin pemerataan pembagian kesejahteraan sebagaimana mestinya dalam institusi keadilan sosial politik. la lebih memilih negara universal. Sayyid Qutb melihat pentingnya partisipasi politik rakyat melalui musyawarah. Prinsipnya bahwa umat Islam dimungkinkan bisa berpartisipasi dalam mengatur segala urusannya. (Muhammad, 2001)

Dalam pandangan Taqiyuddin An-Nabhani, mendirikan negara (khilafah) adalah fardhu bagi seluruh kaum muslimin adalah sesuatu yang pasti dan tidak ada pilihan dalam rangka menegakkannya. Mengabaikan pelaksanaannya merupakan kemaksiatan yang paling besar dan Allah akan mengazab dengan azab yang amat pedih. Menurut Taqiyuddin An-Nabhani, dalil tentang pengangkatan khalifah hukumnya wajib bagi seluruh kaum muslimin adalah as-Sunnah dan ljma Sahabat (AnNabhani, 1994)

Dari argumentasi peristilahan daulah (negara) dan landasan normatif mendirikan negara tersebut, penulis melihat bahwa sebenarnya para penganjur sekularisasi mencoba mengarahkan kaum muslimin untuk menatap realitas kebangkitan Barat yang maju karena telah memisahkan agama dengan kehidupan mereka. Menurut penulis, kaum muslimin tidak seharusnya belajar dari sejarah keberhasilan Barat yang berpaham sekuler tersebut. Jika kaum muslimin mau bangkit maka pilihan satu-satunya mengupayakan kembali diterapkannya syariat Islam dalam seluruh aspek kehidupan. Sebab, kemunduran kaum muslimin justru terjadi karena telah meninggalkan ajaran Islam. Penulis melihat pandangan kritis para penganjur sekularisasi tidak mampu menampilkan logika ilmiah yang memadai guna mendukung gagasan privatisasi negara yang di kedepankannya.

Pernyataan agama terpisah dari negara dan tidak perlu formalisasi syariah merupakan paham sekuler yang digagas oleh kalangan Sekularis. Pandangan paham ini berujung kepada 
pengeliminasian sejarah dan penganuliran eksistensi negara (khilafah). Menurut penulis, langkah seperti ini merupakan upaya penarikan kesimpulan yang tidak berdasar secara ilmiah. Sebab secara historis dan empiris, Islam pernah dipayungi oleh negara (khilafah) yang mengemban misi keagamaan ke seluruh dunia meski tidak sempat menguasai dunia, tapi paling tidak dua pertiga dunia bisa dikuasainya.

Selain itu, sejarah telah mencatat bahwa kejayaan agama (Islam) dan kemuliaan umatnya (penganutnya), justru dicapai ketika misi agama (Islam) diemban oleh negara (khilafah). Selama lebih dari 13 abad -suatu masa yang amat panjang, sedangkan Barat menguasai dunia belum satu abadIslam pernah menoreh tinta emas kejayaannya dalam lembaran sejarah masa lalu dan realita itu tidak terbantahkan. Realitas ini merupakan jawaban ketidakterpisahan agama (Islam) dan negara, sekaligus respon aktualisasi ajaran Islam dalam institusi formal.

Benar, kita tidak hanya memperhatikan masa lalu kita, tetapi harus memperhatikan masa sekarang dan masa depan. Sejarah adalah fakta masa lalu. Sejarah berguna untuk refleksi masa sekarang dan masa depan. Signifikansi masa lalu (kejayaan umat Islam) adalah untuk merubah masa sekarang, menuju masa depan yang cemerlang. Harus dipahami, bahwa sampai kapanpun (bahkan hingga hari kiamat), seorang muslim wajib menyandarkan setiap perbuatannya dengan perilaku Rasulullah dan sahabat. Rujukan kaum muslimin adalah al-Quran dan Sunnah. AlQuran dan Sunnah adalah masa lalu, tetapi ia tetap harus dijadikan rujukan, ukuran, agar kita bisa melihat kondisi kita sekarang.

Saat ini kehidupan kaum muslimin tidak berjalan seperti kondisi ideal seperti yang telah dipraktekkan oleh Rasulullah dan sahabatnya. Dengan realitas kehidupan yang tidak Islami ini, maka wajar jika kaum muslimin merefleksikan sejarah kejayaannya untuk menggagas masa depan yang cemerlang, yaitu masa depan yang sesuai dengan sunnah Rasulullah dan al-Quran, sebagaimana capaian masa lalu kaum muslimin. Sejujurnya, bahwa Demokrasi adalah sistem pemerintahan produk masa lalu. Orang Barat tidak mencampakkan produk masa lalu dan menggantikannya dengan produk baru. Tetapi, orang Barat selalu menjadikan produk masa lalunya, semisal Demokrasi, sebagai acuan masa sekarang untuk menggagas masa depan mereka. Ironi, jika kaum muslimin mengecam gagasan dan upaya untuk kembali mendirikan khilafah Islam. Sebab, telah terbukti bahwa penerapan Islam baru bisa sempurna dengan adanya khilafah Islam.

\section{STRATEGI HIZBUT TAHRIR DALAM MENUJUDKAN KHILAFAH}

Strategi yang dilakukan HizbutTahrir dalam rangka mewujudkan visi dan misi gerakannya; yakni 
Menegakkan Khilafah Islam Di Indonesia dibagi dalam dua periode. Yakni pada masa atau rezim Orde baru dan yang kedua masa atau rezim reformasi/sekarang ini.

Pada periode pertama, pada masa atau rezim Orde baru yakni dibawah pemerintahan Soeharto, Hizbut-tahrir Indonesia melakukan strategi gerakan secara tertutup/ Under ground. pada masa rezim soeharto; pemberlakuan Azas tungal pancasila dan de-Islamisasi politik membuat gerakan-gerakan Islam termasuk didalamnya Hizbut-tahrir terpaksa melakukan gerakan bawah tanah. Karena memang pada masa itu, Islam dan aktivis islam dijadikan musuh utama oleh rezim soeharto pasca tuntuhnya komunisme. Akbatnya pembunahan, penangkapan dan intimidasi terhadap para aktivis Islam menjadi sesuatu yang tidak bisa dielakkan. Kondisi ini berangsur pulih menjelang akhir tahun 1990-an menuju tahun 2000-an. Pada masa ini Hizbut-tahrir berada pada fase atau tahapan pertama/tahapan Nuqthatul Ibtida (nuqthatul Ibtida merupakan tahapan pertama dari tiga tahapan dakwah dan politik Hizbut-tahrir). Fase nuqthatul Ibtida adalah fase dimana Hizbut-tahrir fokus pada proses rekrutmen yang dikenal dengan Tatsqif wa Takwin; pembinaan dan pengkaderan. Tujuannya adalah untukmemperbesar tubuh Hizb dan memperbanyak sel anggota dan jaringannya. Strategi Tatsqif dan pengkaderan ini dilakukan dengan cara kontak individu (ittisholah fardhiyah), face to face, kos to kos.
Ada juga secara massif dengan mengadakan Training-training/ latihan kepemimpinan maupun Daurah-daurah dirasah IsImiyah. Kelanjutan dan follow up dari kontak fardhiyah dan masif ini adalah dengan membina dan mengkader mereka dalam halqah-halqah. Di forum halqah-halqah inilah Hizb mentransformasikan ide-ide Islam kepada para peserta halqah. penggunaan kata-kata atau bahasa inggris training motivasi/ achievments motivations biasa digunakan untuk kampus-kampus atau perguruan tinggi negeri dan swasta Islam. Sementara untuk kampus-kampus atau perrguruan tinnggi negeri dan swasta umum biasa menggunakan bahasa Arabseperti daurah dirasah Islamiyah. Hal ini dilakukan karena memang untuk menarik minat dari mahasiswa itu sendiri. Ide-ide yang di kaji dalam halqah ini adalah kitabkitab yang sudah di tabanni oleh Hizbut-tahrir. Tentunya kitab ini sudah disediakan oleh Hizbut-tahrir pusat, dan Hizbut-tahrir yang ada di indonesia (HTI) maupun negara/wilayah lainnya menjadikannya sebagai acuan sekaligus rujukan untuk membina para Anggota hizbut-tahrir. kitabkitab yang ditabanni adalah kitab Mutabanat ( artinya kitab atau buku utama Hizbut-tahrir). Kitab ini merupakan karya yang ditulis Pendiri Hizbut-tahrir sendiri yakni Syaikh Taqiyuddin An-Nabhani. Tujuan dari tabanni ini adalah untuk menyamakan persepsi terhadap seluruh anggota dan kader Hizbuttahrir yang ada di seluruh dunia. 
Sehingga setiap kader dan anggota Hizbut tahrir dimanapun mereka berada pasti memiliki kesamaan ide,pemikiran perasaan dan peraturan. Inilah salahsatu yang menjadikan Hizbut-tahrir menjadi satu-satunya gerakan yang tetap solid dan susah untuk dipecah belah oleh pihak lain.disamping itu untuk menertibkan administrasi, gerak dan langkah Hizbut-Tahrir diseluruh dunia termasuk Indonesia, Amir Hizbut-tahri juga memberikan Qanun Idari dan juga Milaf idariSejenis AD/ART Partai. Dan Berdasarkan Qanun idari dan Milaf idari inilah para Mandub Amir dan Masul menyelesaikan masalah-masalah yang muncul baik internal maupun eksternal partai ditingkat wilayahnya.Halqah yang dilakukan secara kontiniu satu kali dalam seminggu merupakan internalisasi ideologi islam kepada para anggota Syabab hizbut-tahrir, sehingga anggota yang sudah matang tsaqafah Islam dan ideologinya secara sukarela akan menyatakan bergabung dengan Hizbut-tahrir. Disaat itulah saat ia menyatakan bergabung dengan Hizbut-tahrir dan diterima oleh Mas'ulnya (penanggung jawab wilayah mahaliyah; (setingkat

Kabupaten/kota/kecamatan)

tergantung dari sedikit banyaknya anggata HT di wilayah tersebut, maka ia resmi menjadi Kader dan anggota Hizbut-tahrir. Kader dan anggota yang sudah resmi bergabung biasa disebut dengan Syabab Hizbut-tahrir dan ia pun akan bergerak/beraktivitas dan berjuang atas nama Hizbut-tahrir.
Dalam hal keberadaannya sebagai kader dan anggota Hizbut-tahrir, maka Mas'ul (penanggung jawab wilayah) melaporkan anggota dan kadernya kepada Ma (mandub Amir; Pembantu Amir). Ma adalah penanggung jawab Hizbut-tahrir sebuah wilayah setingkat negara. Artinya dimasing-masing negara yang ada anggota dan kader Hizbuttahrirnya maka disana akan ada penanggung jawabnya. Ma inilah nanti yang akan melaporkan dan mengkomunikasikan kepada Amir Hizbut-tahrir yang ada di Pusat. Disamping itu, Amir Hizbut-tahrir juga mengutus/menempatkan orang kepercayaannya kesetiap negara yang ada Anggota dan kader Hizbuttahrirnya; untuk membina,mengarahkan sekaligus menjembatani antara Amir Hizb dengan para anggota dan kader hizbut-tahrir yang ada disetiap wilayah atau negara. Dan Mandub Amir memberikan laporannya kepada Amir Hizbut-tahrir yang ada dipusat. Dan kondisi ini tidak hanya mengenai jumlah dan keberadaan syabab di sebuah daerah saja, melainkan juga gerak dan planning kegiatan Hizbut-tahrir kedepan. Artinya setiap pertumbuhan dan perkembangan Hizbut-tahrir yang ada di Indonesia tidak terlepas dari kontrol dan arahan langsung dari Hizbut Tahrir yang ada di pusat, dalam hal ini Amir Hizbuttahrir.Disinilah peneliti memahami bahwa apa yang di klasifikasikan oleh Patrik Morgan; Hizbut-tahrir merupakan aktor Internasional yang Individunya bergerak atas nama kelompok. Dan strategi dakwah yang 
dilakukan pada tahapan ini lebih kepada pendekatan cultural.

Periode kedua, dalam
perjalanannya memasuki era Reformasi, Hizbut-tahrir mendeklarasikan diri sebagai sebuah Gerakan Islam yang Vokal dan konsern pada penerapan Syariah dan Penegakan Khilafah Islam. Pada periode ini, Hizbut-tahrir menggunakan Strategi secara terbuka. Dalam hal ini peneliti memahami Secara terbuka artinya secara kelembagaan, keberadaan Hizbut-tahrir diakui secara legal oleh Pemerintah, hal ini ditandai dengan dikeluarkannya SK dari Kemendagri dan Kesbangpol RI, meskipun itu dalam bentuk Ormas. penuturan dari DPP HTI, keberadaan Hizbuttahrir sebagai Ormas Islam di Indonesia merupakan strategi agar dapat beergerak secara legal dan dapat diterima dengan mudah oleh pemerintah dan rakyat Indonesia. Meskipun aktivitas yang dilakukan oleh Hizbut-tahrir adalah aktivitas dakwah namun bersifat politis. Bagi Hizbut-tahrir fungsi partai politik itu adalah tidak hanya meraih suara pada masa momen tertentu seperti pemilu atau pilkada. Namun fungsi edukasi dan agregasi jauh lebih penting. Dan dua fungsi inilah yang konsern digarap oleh HTI. Pada tahapan kedua ini; Hizbut-tahrir menyatakan secara langsung dan terbuka apa yang menjadi visi dan misi gerakannya; meskipun itu berbeda dengan sistem dan asas negara Republik Indonesia maupun pemerintah. Hal ini dilakukan oleh Hizbut-tahrir agar seluruh elemen masyarakat dan pemerintah memahami apa yang sebenarnya menjadi tujuan Hizbut-tahrir. strategi ini juga memudahkan bagi hizbuttahrir untuk memetakan Siapa yang pro terhadap Hizbut-tahrir, siapa yang netral dan siapa yang menentang dan menghalang-halangi tercapainya visi dan misi Hizbuttahrir tersebut. menurut peneliti, hal ini memiliki dampak positif dan negatif; dampak positifnya adalah hizbut-tahrir dapat memetakan siapa-siapa saja yang bisa dijadikan kawan, sekaligus pendukung dan bersinergi terhadap dakwah dan politik Hizbut-tahrir. Sehingga sedini mungkin dapat dirangkul sebelum dipengaruhi oleh pihak-pihak lain yang memusuhi dakwah dan aktivitas politik hizbut-tahrir; baik itu datangnya dari pemerintah maupun, gerakan dan ormas Islam maupun LSM-LSM nasionalis, liberal dan LSM komperador lainnya. Sedangkan dampak negatifnya adalah; Hizbut-tahrir rentan untuk di bubarkan dan dapat dengan mudah di berangus, karena disaat itu Tubuh dan bangunan Struktur Hizbut-tahrir maupun massa pendukungnya belum besar. Namun dibalik itu semua, tentu strategi yang dibuat dan telah dilakukan oleh Hizbuttahrir itu sendiri sudah dipertimbangkan dengan matang. Karena disetiap negeri Islam tempat Hizbut-tahrir bergerak dan beraktivitas kondisinya tidaklah sama. Misalnya di bagian asia tenngah dan negeri-negeri Arab; aktivis Hizbut-tahrir disana dibunuh, ditangnkapi, disiksa dan intimidasi bahkan organisasinya terlarang, namun kondisi itu tidak terjadi di 
Indonesia, Malaysia bahkan di sebahagian negara Eropa Barat Hizbut-tahrir berkembang dengan Pesat.

Setelah Hizb dapat membentuk sekelompok partai sebagaimana yang dimaksud di atas, juga setelah masyarakat mulai merasakan kehadirannya, mengenal ide-ide dan cita-citanya, pada saat itu sampailah Hizb ke tahap kedua.

Tahap keduaadalah tahap berinteraksi dengan masyarakat (Tafa'ul Ma'a Ummah ) tahapan ini disebut juga dengan fase Nuqthatul Intilaq. nuqthatul intilaq; adalah titik tolak dakwah; fase dimana dakwah dan aktivitas Hizbut-tahrir menyebar ke berbagai penjuru yang ada di dunia, termasuk Indonesia. Pada fase ini hizbut-tahrir berkembang dan men yebar seiring dengan bertambahnya para anggota dan kader Hizbut-tahrir. Anggota dan Kader yang awalnya berasal dari Palestina ini kemudian menyebar keberbagai negara seperti; Yordania,Lebanon, Irak, turki, Mesir, Pakistan, malaysia, Indonesia dan lain-lain. Tujuan dari tahapan ini adalah agar umat turut memikul kewajiban menerapkan Islam serta menjadikannya sebagai masalah utama dalam hidupnya. Caranya, yaitu dengan menggugah kesadaran dan membentuk opini umum pada masyarakat terhadap ide-ide dan hukum-hukum Islam yang telah ditabanni oleh Hizb, sehingga mereka menjadikan ide-ide dan hukum-hukum tersebut sebagai pemikiran-pemikiran mereka, yang mereka perjuangkan di tengahtengah kehidupan, dan mereka akan berjalan bersama-sama Hizb dalam usahanya menegakkan Daulah Khilafah, mengangkat seorang Khalifah untuk melangsungkan kehidupan Islam dan mengemban dakwah Islam ke seluruh penjuru dunia.Pada tahap ini Hizb mulai beralih menyampaikan dakwah kepada masyarakat banyak secara kolektif.

Pada tahap ini Hizb melakukan kegiatan-kegiatan seperti berikut:

1. Pembinaan Tsaqafah

Murakkazah (intensif)

melalui halqah-halqah Hizb untuk para pengikutnya, dalam rangka membentuk kerangka gerakan dan memperbanyak pengikut serta mewujudkan pribadipribadi yang islami, yang mampu memikul tugas dakwah dan siap mengarungi samudera cobaan dengan pergolakan pemikiran, serta perjuangan politik.

2. Pembinaan Tsaqafah

Jama'iyah bagi umat dengan cara menyampaikan ide-ide dan hukum-hukum Islam yang telah ditetapkan Hizb, secara terbuka kepada masyarakat umum. Aktivitas ini dapat dilakukan melalui pengajian-pengajian di masjid, di aula atau di tempat-tempat pertemuan umum lainnya. Bisa juga melalui media massa, buku-buku, atau 
selebaran-selebaran.

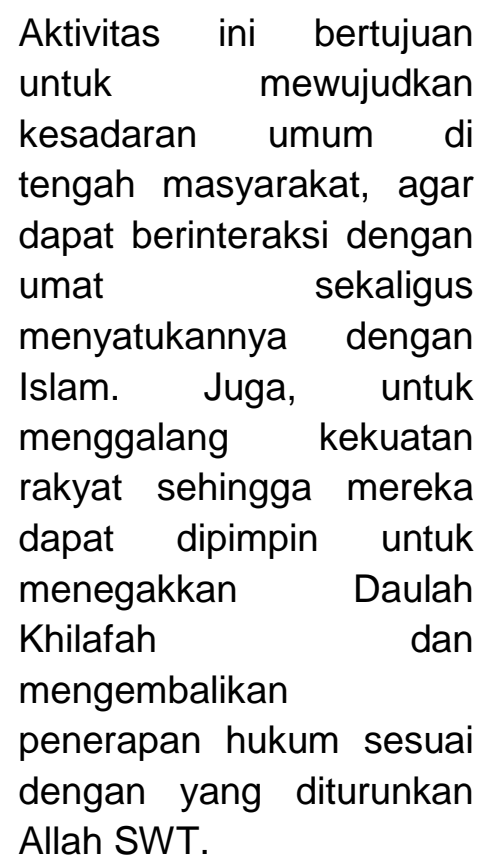

3. Ash-Shira'ul

Fikri (Pergolakan

Pemikiran) untuk menentang ideologi, peraturan-peraturan dan ide-ide kufur, selain untuk menentang aqidah yang rusak, ide-ide yang sesat dan pemahamanpemahaman yang rancu. Aktivitas ini dilakukan dengan cara menjelaskan kepalsuan, kekeliruan dan kontradiksi ide-ide tersebut dengan Islam, untuk memurnikan dan menyelamatkan

masyarakat dari ide-ide yang sesat itu, serta dari pengaruh dan dampak buruknya.

4. Al-Kifaahus

Siyasi (Perjuangan Politik) yang mencakup aktivitasaktivitas: a. Berjuang menghadapi negara-negara kafir imperialis yang menguasai atau mendominasi negerinegeri Islam; berjuang menghadapi segala bentuk penjajahan, baik penjajahan pemikiran, politik, ekonomi, maupun militer. Mengungkap strategi yang mereka rancang,

membongkar persekongkolan mereka, demi untuk menyelamatkan umat dari kekuasaan mereka dan membebaskannya dari seluruh pengaruh dominasi mereka.

b. Menentang para penguasa di negaranegara Arab maupun negeri-negeri Islam lainnya;

mengungkapkan

(rencana) kejahatan mereka;

menyampaikan

nasihat dan kritik kepada mereka. Dan berusaha untuk meluruskan mereka setiap kali mereka merampas hak-hak rakyat atau pada saat mereka melalaikan kewajibannya terhadap umat, atau pada saat mengabaikan salah 
satu urusan mereka. Disamping berusaha untuk menggulingkan sistem pemerintahan mereka, yang menerapkan perundang-undangan dan hukum-hukum kufur, yaitu dengan tujuan menegakkan dan menerapkan hukum Islam untuk menggantikan hukumhukum kufur tersebut.

5. Mengangkat

dan menetapkan kemaslahatan umat, yaitu dengan cara melayani dan mengatur seluruh urusan umat, sesuai dengan hukum-hukum syara'.

Dalam melakukan semua aktivitas ini, Hizb senantiasa mengikuti jejak Rasulullah SAW, khususnya setelah turun kepada beliau firman Allah SWT:

Artinya; "Maka sampaikanlah olehmu secara terang-terangan segala yang diperintahkan (kepadamu), dan berpalinglah dari orang-orang musyrik." (Q.S. Al-Hijr:

Ketika itu beliau langsung menampakkan risalahnya secara terang-terangan dengan mengajak orang-orang Quraisy pergi berkumpul ke bukit Shafa, kemudian menyampaikan kepada mereka bahwa sesungguhnya beliau adalah seorang nabi yang diutus, dan beliau meminta agar mereka mengimaninya. Beliau menyampaikan dakwahnya kepada masyarakat Quraisy sebagaimana beliau melakukannya kepada individu-individu. Beliau menentang orang-orang Quraisy, tuhan-tuhan sesembahan mereka, keyakinankeyakinan, dan ide-ide mereka; dengan cara menjelaskan kepalsuan, dan kerusakannya. Beliaupun mencela dan menyerang mereka sebagaimana yang beliau lakukan terhadap keyakinankeyakinan, dan ide-ide yang ada pada saat itu.

Sedangkan ayat-ayat Al-Quran yang turun kepada beliau secara beruntun selalu terkait dengan kondisi yang ada pada saat itu. Ayat Al-Quran turun dengan menyerang kebiasaan-kebiasaan buruk mereka, seperti; memakan harta riba, mengubur hidup-hidup anak wanita, curang dalam timbangan, ataupun berzina. Ayat-ayat itu juga menyerang para pemimpin dan tokoh-tokoh Quraisy, memberinya predikat sebagai orang-orang bodoh, termasuk kepada nenek moyang mereka; disertai dengan pengungkapan terhadap persekongkolan-persekongkolan yang mereka rencanakan untuk menentang Rasul SAW, dakwah beliau dan para sahabat beliau.

Hizb dalam mengembangkan ide-idenya; menentang ide-ide lain (yang bertentangan dengan Islam) dan kelompok-kelompok politik (yang tak berasaskan Islam); melawan negeri-negeri kafir; atau dalam menentang para penguasa, senantiasa bersikap terbuka, terangterangan, dan menantang, tidak berbasa-basi, berpura-pura ataupun berkompromi; tidak berputar-putar dan tidak pula mementingkan 
keselamatan diri sendiri, tanpa memandang hasil dan keadaan yang terjadi. Hizb tetap akan menghadapi setiap hal yang bertentangan dengan Islam dan hukumhukumnya. Suatu keadaan yang akan membawanya kepada bahaya berupa penyiksaan pedih dari para penguasa, perlawanan kelompokkelompok politik non Islami dan para pengemban dakwah (yang bertentangan dengan Hizb), bahkan kadang-kadang menghadapi perlawanan mayoritas masyarakat.

Dalam hal ini Hizb selalu meneladani sikap Rasulullah SAW. Beliau datang dengan membawa risalah Islam ke dunia ini dengan cara yang menantang, terangterangan, namun yakin terhadap kebenaran yang diserukannya, dan menentang kekufuran berikut ideidenya yang ada di seluruh dunia. Beliau menyatakan perang atas seluruh manusia, tanpa memandang lagi warna kulitbaik yang hitam maupun yang putih- tanpa memperhitungkan adat-istiadat, agama-agama, kepercayaankepercayaan, para penguasa ataupun masyarakat-nya. Beliau tidak menoleh sedikit pun, kecuali kepada risalah Islam. Beliau memulai dakwahnya di tengahtengah kaum musyrikin Quraisy, dengan menyebut tuhan-tuhan sesembahan mereka disertai celaan, menentang segala sesuatu yang menjadi keyakinan mereka dan memandang rendah sembahan mereka. Sedangkan beliau -dalam melakukan semua ini- adalah sendirian, tanpa seorang pun yang mendampinginya, tanpa senjata apapun kecuali keyakinannya yang amat mendalam terhadap risalah Islam yang dibawanya.

Tahapan ketiga adalah istilamu al-hukmi yakni penyerahan kekuasaan. Pada tahapan ini hizbut tahrir menjadikan para pemilik kekuatan sebagai jalan untuk mengambilalih kekuasaan. Para pemilik kekuasaan inilah yang disebut dengan ahl an-nushrah (Militer (TNI), Polri, Ulama', Tokoh Masyarakat yang berpengaruh, Cendikiawan, para Pengusaha). Ahl an-nushrah dalam hal memberikan dukungannya haruslah berdasarkan kesadaran Islam bukan atas tekanan atau desakan dari masyarakat (artinya tegaknya khilafah bukanlah dengan menggunakan people power), karena hal ini bisa menjadi boomerang bagi tegaknya khilafah dimasa depan. Memang benar, jika dikatakan bahwa ahl an-nushrah bisa saja memberi dukungan kepada dakwah, karena adanya desakan umat melalui people power. Namun, yang harus dicatat, bahwa dukungan mereka dalam kondisi seperti ini, bukanlah dukungan karena lahir dari keyakinan, melainkan dukungan karena faktor preassure (tekanan). Dukungan seperti ini sangat lemah, dan tidak akan bisa menjadi pilar tegaknya negara. Ketika kita memahami, bahwa negara adalah entitas pelaksana teknis yang mengimplementasikan kumpulan pemahaman, standarisasi dan keyakinan yang diterima oleh umat. Pertanyaannya, mungkinkah negara seperti ini bisa tegak, jika penopang kekuasaannya ternyata tidak menerima pemahaman, standarisasi 
dan keyakinan tersebut? Jawabannya jelas tidak mungkin. Dukungan seperti ini bisa kita sebut sebagai dukungan semu, bukan dukungan hakiki. Padahal, yang dibutuhkan adalah dukungan yang hakiki.

Itulah, mengapa Rasulullah menolak tawaran pemuka kabilah Arab Quraisy, yang menawarkan kekuasaan kepada Nabi, tetapi ditolak oleh Nabi, ketika mereka dengan nyata tidak meyakini risalah yang diemban oleh Nabi saw. Dan, itulah yang disebutkan dalam soal jawab yang lalu, bahwa salah satu syarat dalam nushrah adalah agar ahl an-nushrah yang memberikan dukungannya haruslah mengimani Islam, dan meyakininya.

Ini satu hal. Hal lain, bahwa proses perubahan melalui people power ini salah karena cara seperti ini bertentangan dengan metode Rasulullah jelas sekali bisa diteliti melalui sejumlah riwayat yang menjelaskan tentang Thalab anNushrah. Antara lain, sebagai berikut:

1. Nabi saw. meminta orang yang hendak diambil nushrah-nya untuk kepentingan Islam agar mereka pertama kali mengimani dan membenarkan Islam, sebagaimana yang telah dinyatakan dalam nasnas sebelumnya. Misalnya: Beliau pun meminta mereka agar mereka membenarkan beliau dan bersedia melindungi beliau. (As- suhayli, as-Sirah anNabawiyyah li ibn Hisyam, juz II, hal. 173). Dengan syarat ini, jelas ada perbedaan antara mencari dukungan untuk pribadi Rasul saw. minus dukungan terhadap dakwah yang beliau emban, dengan dukungan terhadap beliau dalam kapasitasnya sebagai pengemban dakwah, dalam arti perlindunganbukan saja terhadap pribadi beliau, tetapi jugaterhadap dakwah yang diembannya. Karena, konsekuensi dari nushrah ini adalah adanya kesiapan untuk menghadapi musuhmusuh dakwah, serta menghalangi mereka agar tidak menimpakan penganiayaan terhadap dakwah dan para pengikutnya.

Semua nas yang ada membuktikan, bahwa Rasulullah saw. telah mengajukan syarat kepada orang yang akan dimintai nushrah agar pertama-tama mereka memeluk Islam, baru kemudian nushrah tersebut bisa diminta dari mereka. Ini merupakan konsekuensi logis. Sebab, bagaimana mungkin keikhlasan dan 
konsistensi salah satu pihak terhadap dakwah serta dukungan mereka terhadapnya bisa dijamin, sementara pihak yang mendukung dakwah itu ternyata tidak meyakini dakwah tersebut? Dari sinilah, maka Nabi saw. begitu konsisten dalam setiap negosiasi yang beliau lakukan untuk mencari nushrahdengan

menetapkan syaratagar ahl an-nushrah (para penolong) tersebut terlebih dahulu memeluk Islam, sebelum yang lain.

2. Dalam sirah Nabi saw. terutama yang berkaitan dengan thalab annushrah, terbukti bahwa beliau selalu mencari nushrah dengan dua tujuan:

Pertama, beliau mencari nushrah dalam rangka melindungi penyampaian dakwah, sehingga dakwah tersebut tersebar dengan mudah di tengah masyarakat, sementara dakwahnya tetap terpelihara, jauh dari perlakuan buruk, baik terhadap dakwah maupun para pengikutnya.

Kedua, beliau selalu mencari nushrah dalam rangka mengambilalih kendali pemerintahan

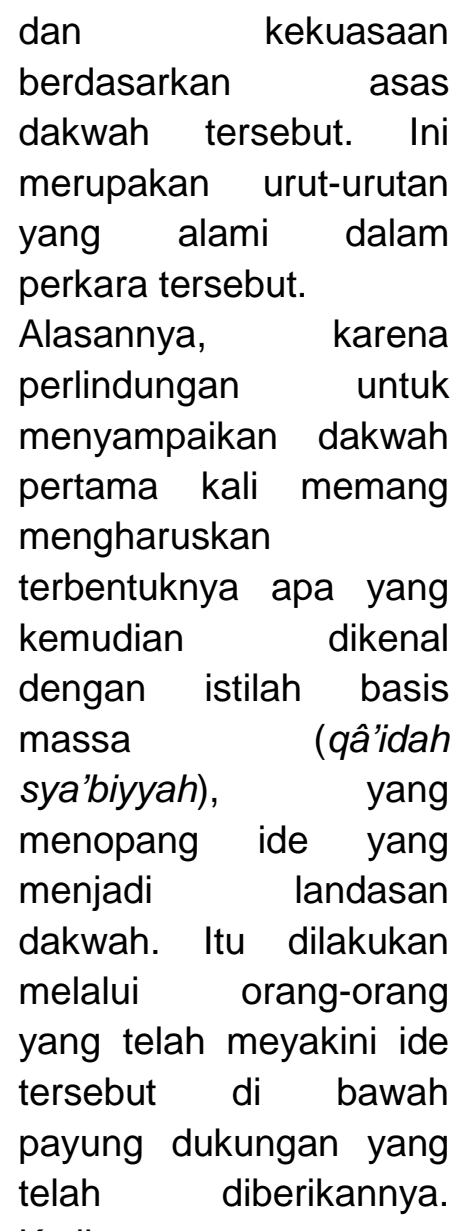

Ketika orang-orang yang meyakini ide tersebut dan mereka yang siap berkorban di jalannya semakin banyak, berarti telah terbentuk landasan yang mantap dan basis yang luas, yang bisa menjadi sandaran pemerintahan dan kekuasaan.

Ini merujuk pada uraian Ibn Ishaq inwal aktivitas Rasul saw. pasca perjalanan beliau dari Thâ'if untuk mencari nushrah. Juga seperti yang terlihat dengan jelas dalam riwayat alHakim dalam al- 


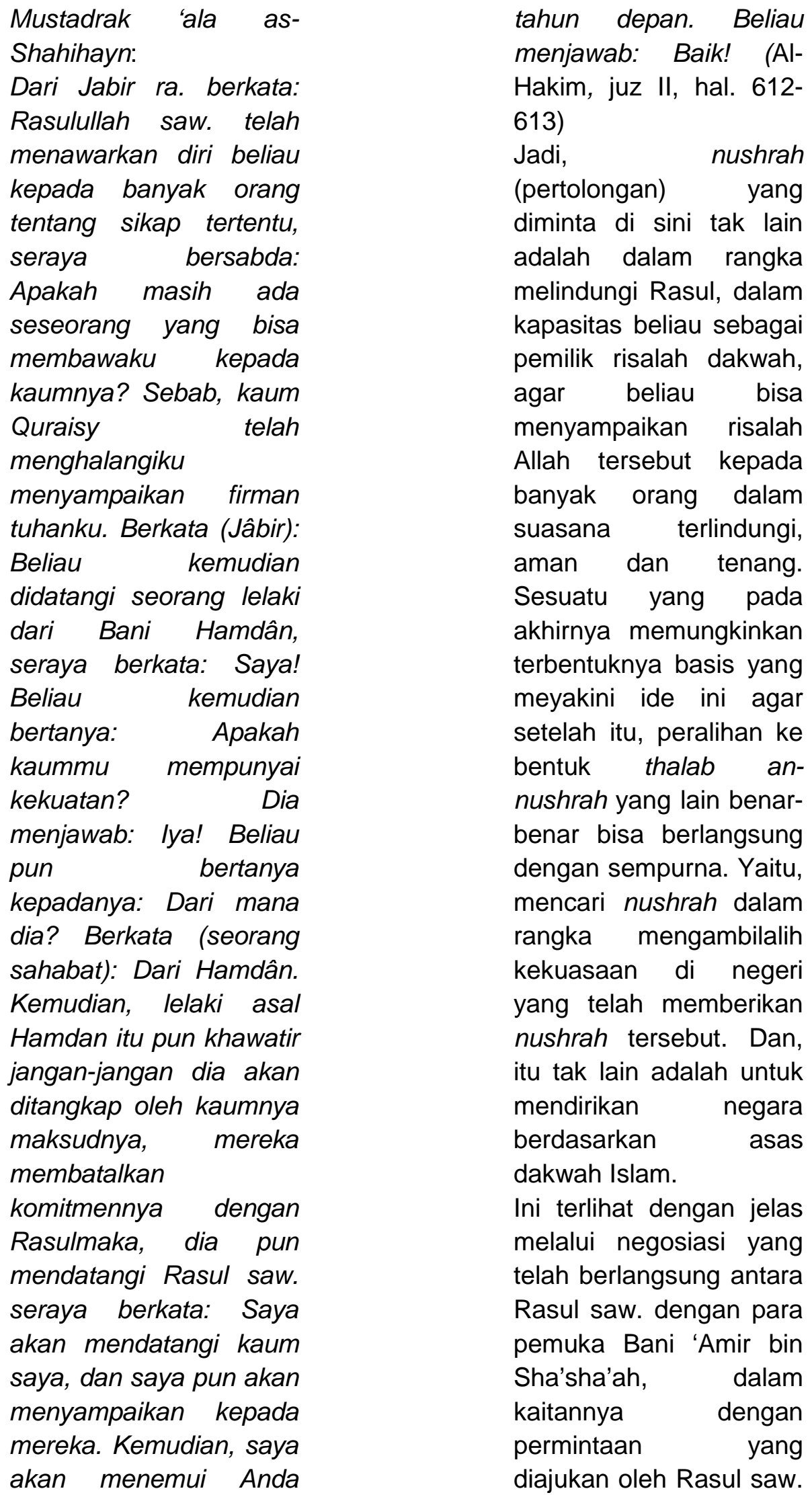


kepada mereka. Seorang tokoh Bani 'Amir bin Sha'sha'ah kemudian menuturkan kepada syaikh (ketua suku) mereka kriteria permintaan ini, dengan ungkapan mereka: Kami telah didatangi oleh seorang pemuda, yang menganggap dirinya sebagai Nabi. Dia menyerukan kepada kami, agar kami melindunginya, dan berdiri di pihaknya, serta kami membawanya masuk ke negeri kami. (Ibnu Hisyam)

Bani 'Amir paham benar, bahwa implikasi memenuhi permintaan nushrah ini akan menjadikan Nabi saw. sebagai pemegang pemerintahan dan kekuasaan atas seluruh bangsa Arab, ketika Allah telah memenangkan beliau atas mereka, karena beliau telah menggunakan nushrah yang telah mereka berikan ini. Di sinilah, maka mereka pun menginginkan urusan ini. Dengan kata lain, pemerintahan dan kekuasaan pasca Nabi saw. itu tak lain harus menjadi milik Bani 'Amir secara sah, sebagai harga yang harus dibayar atas pengorbanan yang telah mereka berikan. Ini tampak dalam ungkapan juru runding Bani 'Amir, yang bernama Bayharah bin Firas.

3. Dari kasus di atas, juga bisa disimpulkan, bahwa beliau saw. menolak kekuatan yang siap memberikan nushrah dengan kompensasi apapun, misalnya dengan syarat tokohtokoh mereka akan memerintah dan berkuasa, dengan harga atau kompensasi tertentu. Inilah yang terlihat dengan jelas pada point sebelumnya, dalam negosiasi antara Nabi saw. dengan Bani 'Amir bin Sha'sha'ah.

Alasannya, karena dakwah ini merupakan dakwah kepada Allah, maka syarat mendasar orang yang mengimani dakwah dan siap menolongnya adalah ikhlas semata karena Allah, serta mengharapkan ridhaNya. Keduanya merupakan tujuan yang hendak diraih di balik nushrah dan pengorbanan tersebut, bukan ambisi untuk berkuasa, ataupun mendambakan kekuasaan. Sebab, 


\begin{abstract}
tujuan yang ditetapkan oleh manusia terhadap sesuatu akan menentukan perjalanan aktivitasnya, serta menentukan sejauh mana ia dipertahankan, termasuk besar-kecilnya pengorbanan untuk mewujudkannya.
\end{abstract}

4. Dari sirah Nabi saw. yang berkaitan dengan thalab an-nushrah, tampak bahwa Nabi saw. tidak pernah mencari nushrah para tokohtokoh itu semata-mata karena mereka adalah para pemuka kabilah dan bangsawan. Namun, beliau mencari kekuatan yang dimiliki para pemuka itu di negeri mereka, yang bisa digunakan untuk menghadapi musuhmusuh negara yang hendak dibangun. Jika beliau tidak menemukan sesuatu yang bisa digunakan untuk melindungi dakwah pada kekuatan tersebut, maka beliau tidak akan mengajukan kepada mereka permintaan nushrah, selain hanya mengingatkan mereka akan kewajiban mereka kepada Allah.

Ini telah dibuktikan melalui beberapa riwayat sirah, dengan redaksi: Ketika kabilah Bakar bin
Wa'il datang ke Makkah untuk menunaikan haji, Rasulullah saw. meminta Abu Bakar: Datangilah mereka, kemudian bawalah aku kepada mereka. Maka, dia pun mendatangi mereka, dan membawa beliau kepada mereka. Beliau bertanya kepada mereka: Bagaimana dengan jumlah kalian? Mereka menjawab: Banyak, seperti embun pagi. Beliau bertanya: Bagaimana dengan kekuatannya? Mereka menjawab: Tanpa kekuatan! Kami bertetangga dengan Persia, dan kami tidak mampu mempertahankan diri (dari serangan) mereka, dan kami tidak mampu melindungi dari terhadap mereka. Di sini, Rasulullah hanya perlu mengingatkan mereka pada Allah, serta memberitahukan kepada mereka, bahwa beliau adalah utusan Allah.

5. Nushrah yang diminta oleh Rasul dari para pemuka kabilah untuk kepentingan dakwah juga disyaratkan tidak terikat dengan perjanjian internasional, yang bertentangan dengan dakwah, sedangkan mereka tidak bisa 


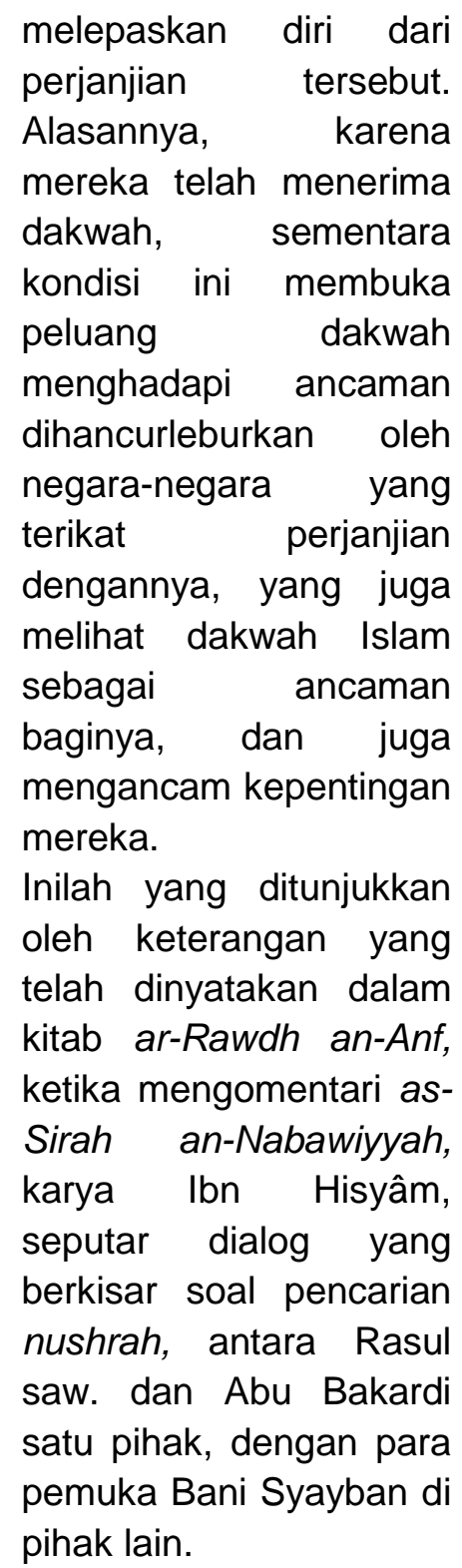

Abu Bakar berkata kepada salah seorang pemuka Bani Syayban, namanya Mafruq: Bagaimana dengan jumlah kalian? Mafruq menjawab: Kami tidak lebih dari seribu, dan seribu orang tak akan pernah kalah, karena jumlahnya yang minim! Abû Bakar bertanya lagi: Lalu, bagaimana dengan pertahanan kalian?
Mafruq menjawab: Kita
harus bekerja keras.
Dan, tiap kaum
mempunyai peluang dan
kesempatan! Abu Bakar
bertanya lagi:

Bagaimana peperangan yang terjadi di antara kalian dengan musuh kalian? Mafrûq menjawab: Kami akan sangat marah, ketika kami benar-benar bertemu, dan kami sangat ingin bertemu, ketika kami sedang marah. Kami sangat mementingkan kebaikan ketimbang anak-anak kami, dan lebih mementingkan senjata ketimbang makanan! Kemenangan itu datangnya dari Allah; sekali waktu dipergilirkan kepada kami, dan sekali waktu kami kalah! Tampaknya Anda saudara Quraisy? (yang dimaksud Mafruq: Apakah Anda Muhammad saw. orang Quraisy, pemilik risalah dakwah?) Abû Bakar menjawab: Apakah beritanya benar-benar telah sampai kepada kalian, bahwa beliau adalah utusan Allah? Itu dia orangnya (sembari menunjuk ke arah Rasulullah saw.) Mafruq menjawab: Memang 


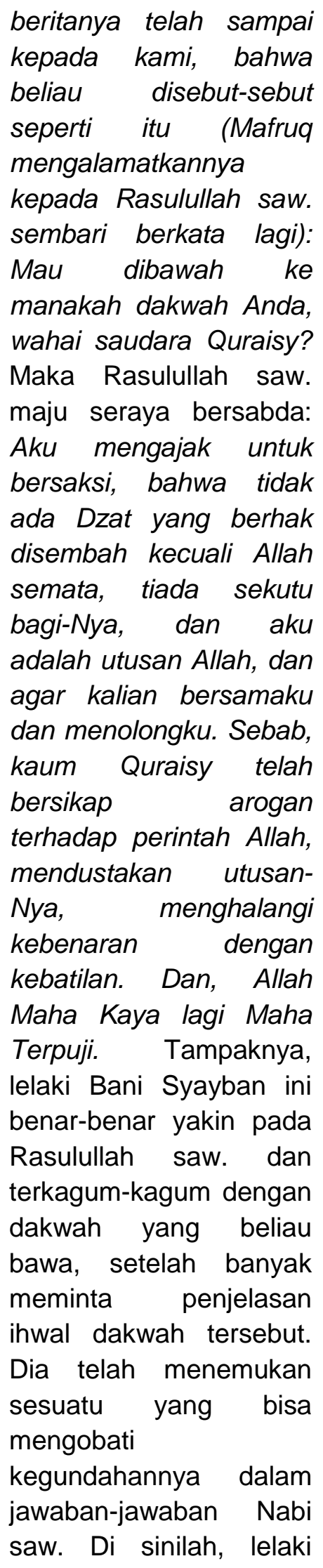

Bani Syaybân itu menjadi terasah. Dia kemudian berkata kepada Nabi saw: Demi Allah, sungguh dusta kaum yang telah mendustakan Anda, dan arogan terhadap Anda! Kemudian berkata Hani' bin Qubayshah, tetua Bani Syayban, dan pemangku adat mereka: Saya telah mendengarkan ucapan Anda, wahai saudara Quraisy. Saya berpendapat, bahwa dengan meninggalkan agama kami, kemudian kami mengikuti agama Anda, karena satu forum yang telah Anda adakan dengan kami ini baik yang pertama dan kapan saja tidak mampu menggelincirkan pandangan, dan juga tidak cukup untuk melihat implikasi (ke depan). Tetapi, ketergelinciran itu justru terjadi karena ketergesagesaan! Di belakang kami ada kaum, dimana kami tidak suka mengikat mereka dengan suatu perjanjian. Namun, jika mereka merujuknya kami juga sama, dan jika mereka menganggapnya, maka kami pun sama.

Al-Mutsni bin Haritsah, salah seorang tetua Bani 
Syayban, dan penentu peperangan mereka, kemudian berbicara. Dia menyatakan, bahwa Bani Syaybanitu terletak di suatu negeri, antara sungai Kisra dan perairan bangsa Arab maksudnya, berbatasan dengan negeri Persia. Dia kemudian mengemukakan apa yang menjadi kemampuan kaumnya untuk diberikan kepada Nabi saw. dalam soal nushrah yang beliau minta dari mereka, dengan

mempertimbangkan

posisi negerinya dan hubungan kaumnya dengan negara Persia. Dia berkata: Mengenai sungai Kisra, pada dasarnya kesalahan pemiliknya tidak bisa dimaafkan, dan alasannya juga tidak bisa diterima, sementara perairan Arab, kesalahan (pemilik)-nya bisa dimaafkan, dan alasannya pun bisa diterima! Dan, kami harus mengakhiri sebuah perjanjian yang telah diambil oleh Raja Kisra terhadap diri kami, dimana kami tidak boleh membuat ulah, dan kami tidak akan mengakomodasi orang yang membuat ulah!
Saya melihat, bahwa perkara yang Anda serukan kepada kami adalah sesuatu yang dibenci oleh raja-raja. Jika Anda berkenan agar kami bisa mengakomodasi Anda, dan menolong Anda, termasuk perairan Arab, maka pasti akan kami lakukan!

Rasulullah saw. menjawab: "Kalian tidak menolak dengan cara yang buruk, sebab kalian sengat jelas dalam mengutarakan kejujuran. Sesungguhnya agama Allah ini tidak akan pernah Dia tolong, kecuali melalui orang yang menguasainya dari seluruh aspek!'

Persia baru saja terlibat dalam peperangan sengit dengan negara Romawi, sementara ia akan memetik kemenangan, sebagaimana yang diisyaratkan pada permulaan surat ar-Rûm dalam al-Qur'an alKarim. Lebih-lebih telah ada perjanjian internasional antara Bani Syayban dimana mereka kedudukannya sama dengan negara kecil dengan negara besar Persia, agar mereka (Bani Syayban) tidak membuat ulah, dan 




Dalam konteks thalabun nushrah, ada beberapa perkara penting yang harus dimengerti para pengemban dakwah Islam, yaitu:
a. Pengertian thalabun nushrah secara bahasa maupun istilah.
b. Bagaimana suasana thalabun nushrah di Madinah al-Munawarah

dipersiapkan, dan bagaimana suasana itu dipersiapkan pada masa sekarang.

c. Realitas umat sekarang, dari sisi apakah mereka telah memiliki kesiapan untuk menerima perkara yang besar ini, ataukah belum.

d. Bagaimana cara menyempurnakan thalabun nushrah hingga memiliki kapasitas untuk mendorong terjadinya penyerahan kekuasaan?

An-Nushrah dan almunâsharah memiliki makna i'anah 'ala al-amr (menolong atas suatu perkara). Orang Arab menyatakan, "nasharahu 'ala 'adwihi wa yanshuruhu nashran (menolong seseorang atas musuhnya, dan ia sedang memberikan sebuah pertolongan). $\mathrm{Di}$ dalam hadits shahih, Nabi saw bersabda, "Unshur akhaka zhaliman au mazhluman". Makna sabda Nabi saw ini adalah, menolong orang tersebut dari orang yang menzaliminya. Kata bendanya adalah an-nushrah.

Sedangkan menurut istilah, thalabun nushrah adalah aktivitas meminta pertolongan (nushrah) yang dilakukan oleh orang-orang yang memiliki kewenangan (amir) kepada orang-orang yang memiliki kekuasaan untuk tujuan penyerahan kekuasaan dan penegakkan Daulah Islamiyyah, atau untuk tujuan-tujuan lain yang berhubungan dengan dukungan terhadap dakwah, misalnya: 
(1) Untuk melindungi para pengemban dakwah di negeri-negeri Islam, agar mereka mampu menyampaikan maksud dan tujuan dakwah mereka di tengah-tengah masyarakat,

(2) Untuk menyingkirkan berbagai macam keburukan, baik yang akan menimpa maupun yang telah menimpa pengemban dakwah. Misalnya, meminta pertolongan dari tokohtokoh yang memiliki pengaruh pada kekuasaan agar penguasa tidak memasukkan pengemban dakwah ke dalam penjara, atau berdiri di sampingnya ketika pengemban dakwah harus menghadapi persidangan, dan lain sebagainya;

(3) Untuk mempopulerkan dan menunjukkan kekuatan Hizbut Tahrir kepada masyarakat dengan cara memberdayakan orangorang yang memiliki kekuataan dan pengaruh, setelah mereka masuk Islam dan qana'ah terhadap pemikiranpemikiran dan tujuantujuan dakwah Hizbut Tahrir.

Adapun thalabun nushrah yang ditujukan untuk aktivitas istilam al-hukm (penyerahan kekuasaan) dan penegakkan Daulah Khilafah
Islamiyyah, maka ia membutuhkan kondisi-kondisi dan syarat-syarat yang berbeda dengan semua bentuk thalabun nushrah yang telah dijelaskan di atas. Adapun syaratsyarat yang harus dipenuhi adalah sebagai berikut:

1. Terbentuknya opini umum (ra'yu al-'am) tentang Islam dan Hizb yang bersumber dari kesadaran umum (wa'yu al-'am) di suatu negeri Islam.

2. Terpenuhinya syaratsyarat khusus di suatu negeri yang hendak dimintai nushrah. Syaratsyarat yang dimaksud adalah: negeri tersebut memiliki kemampuan untuk melindungi eksistensi dan keberlangsungan Daulah Islamiyyah. Negeri tersebut harus mampu memberikan proteksi mandiri terhadap Daulah Islamiyyah dan tidak di bawah proteksi negara lain, atau dikuasai secara langsung oleh negara lain.

3. Keikhlasan ahlul quwwah dalam menolong dakwah, penerimaan mereka yang sempurna terhadap Islam dan Daulah Islamiyyah, serta tidak adanya keraguan dan kekhawatiran pada diri mereka terhadap kekuatan lain atau negara lain, atau terhadap kelompokkelompok Islam lain maupun kelompok non 
Islam yang memiliki tujuan yang berbeda dengan tujuan Islam.

Thalabun nushrahmin ajli istilam al-hukmi (thalabun nushrah untuk meraih kekuasaan) adalah hukum syariat yang berhubungan erat dengan metode meraih kekuasaan. Penyerahan kekuasaan tidak akan terjadi tanpa adanya aktivitas thalabun nushrah serta terpenuhinya syarat-syarat di atas; sama saja apakah kekuasaan tersebut diserahkan oleh atau diminta dari ahlul quwwah.

Bagaimana Suasana Nushrah Dipersiapkan di Madinah, dan Bagaimana Suasana itu Dipersiapkan Pada Saat Sekarang?

Siapa saja yang mengkaji sirah Nabi saw akan menyaksikan bahwa Nabi saw melakukan beberapa aktivitas penting dan berkesinambungan sebelum mempersiapkan suasana nushrah dan penyerahan kekuasaan di Madinah. Langkah pertama yang beliau lakukan adalah mengontak delegasi suku Khazraj yang berkunjung ke Mekah dan meminta mereka masuk ke dalam Islam. Setelah masuk Islam, Nabi saw memerintahkan mereka kembali ke Madinah untuk mendakwahkan Islam kepada kaumnya. Setibanya di kota Madinah, mereka menampakkan keislaman mereka dan mengajak kaumnya masuk ke dalam Islam. Jumlah kaum Muslim terus bertambah. Pada tahun berikutnya, mereka kembali menemui Rasulullah saw. Jumlah mereka pada saat itu adalah 12 orang.
Nabi saw menerima mereka dan mengutus Mush'ab bin 'Umair ra. untuk menjadi pengajar mereka di Madinah. Akhirnya, melalui tangan Mush'ab bin 'Umair ra, pembesar-pembesar Auz dan Khazraj masuk ke dalam agama Islam dan menunjukkan dukungan dan loyalitas yang amat kuat terhadap Islam. Setelah melihat kesiapan masyarakat Madinah, yang tampak pada masuk Islamnya pembesar-pembesar Auz dan Khazraj serta terbentuknya opini umum tentang Islam yang lahir dari kesadaran umum pada penduduk Madinah, Nabi saw meminta mereka untuk menemui Beliau saw pada musim haji.

Dari sini dapatlah disimpulkan bahwa realitas Madinah sebelum terjadinya bai'at 'Aqabah II bai'at yang menandai terjadinya penyerahan kekuasaan di Madinahadalah realitas yang dipersiapkan untuk pembentukan opini umum membela Islam dengan kekuatan. Artinya, Madinah dipersiapkan sedemikian rupa hingga Islam diterima oleh mayoritas penduduk Madinah dan menjadi opini umum yang mampu mendominasi penganut-penganut agama lain di Madinah. Tidak hanya itu saja, opini umum tersebut juga ditujukan agar masyarakat Madinah siap membela kepemimpinan baruyakni kepemimpinan Rasulullah saw.

Artinya, opini umum di sana dipersiapkan begitu rupa hingga masyarakat Madinah siap menerima kepemimpinan gerakan Nabi saw. Opini umum untuk membela Islam tersebut lahir dari kesadaran umum 
mayoritas masyarakat Madinah dan pembesar-pembesarnya atas hakekat Islam dan atas Rasulullah saw dalam kapasitasnya sebagai Nabi dan pemimpin takattul shahabat. Ringkasnya, opini umum yang terbentuk di Madinah adalah opini umum yang lahir dari kesadaran umum masyarakat Madinah terhadap Islam dan kesadaran mereka untuk membela Rasulullah saw.

Rasulullah saw belum bersedia menerima nushrah li istilam al-hukm, kecuali setelah kondisi-kondisi di atas terwujud dan yakin dengan kesiapan penduduk Madinah. Setelah yakin terhadap kesiapan penduduk Madinah untuk menerima dan membela kekuasaan Islam, Rasulullah saw meminta wakil penduduk Madinah dengan disertai Mush'ab bin 'Umair menemui beliau saw di bukit 'Aqabah.

Tujuan pertemuan itu adalah meminta nushrah dari penduduk Madinah agar menyerahkan kekuasaan mereka di Madinah kepada Rasulullah saw dan meminta kesediaan mereka untuk membela Rasulullah saw dengan harta, anakanak, isteri, dan nyawa mereka. Aktivitas thalabun nushrah di bukit 'Aqabah sebagai langkah muqaddimah istilam al-hukm (penyerahan kekuasaan) menjadi sempurna setelah Nabi saw tiba di Madinah dan menegakkan Daulah Islamiyyah di sana.

Terbentuknya opini umum yang lahir dari kesadaran umum merupakan syarat mutlak yang harus dipenuhi oleh suatu negeri yang hendak ditegakkan thalabun nushrah li istilam al-hukukm. Hanya saja, negeri tersebut juga harus memiliki kemampuan untuk melindungi eksistensi dan kelangsungan Daulah Islamiyyah secara mandiri, dan tidak dibawah kendali atau dominasi negara lain. Opini umum untuk membela Islam, Hizb dan pengikutnya harus lahir dari kesadaran umum untuk membela Islam dan Hizb. Jika kondisi ini tidak terpenuhi, maka di negeri tersebut tidak mungkin ditegakkan aktivitas thalabun nushrah li istilam al-hukm, baik secara syar'iy maupun 'aqliy. Jikalau dipaksakan untuk dilakukan aktivitas nushrah di negeri tersebut, maka selain melanggar ketentuan syariat dalam hal thalabun nushrah, aktivitas tersebut juga akan berujung kepada kegagalan dan kehancuran. Yang dimaksud dengan opini umum pada konteks sekarang adalah, adanya keinginan untuk diatur dan diperintah oleh kekuasaan Islam pada mayoritas kaum Muslim yang ada di sebuah negeri yang layak dilakukan thalabun nushrah. Keinginan tersebut juga harus muncul pada diri ahlu al-quwwah panglima perang, pemimpin kabilah, dan lain sebagainya, dan tidak cukup hanya muncul pada mayoritas kaum Muslim belaka.

Adapun yang dimaksud dengan kesadaran umum (wa'y al'am) adalah kesadaran umum terhadap beberapa hal;

(1) Tentang Islam, terutama pemikiran tentang Khilafah dan kekuasaan;

(2) Permusuhan dan upayaupaya penyesatan yang 


$\begin{array}{lr}\text { dilakukan } & \text { kaum kafir } \\ \text { untuk } & \text { menghalang- } \\ \text { halangi } & \text { tegaknya } \\ \text { Khilafah, } & \end{array}$

(3) Umat tidak akan pernah bisa melepaskan diri dari problematikanya, kecuali jika mereka mampu membebaskan dirinya dari pemerintahan yang menerapkan hukumhukum kufur, dan

(4) Kesadaran terhadap tipu daya dan permainan politik kaum kafir untuk memalingkan umat dari jalan yang benar. Yang dimaksud dengan kesadaran umum di sini bukanlah kesadaran terhadap persoalanpersoalan tertentu, semacam 'aqidah dan syariah secara rinci dan mendalam. Pasalnya, kesadaran seperti ini tidak mungkin diwujudkan kecuali di bawah naungan Daulah Khilafah Islamiyyah.

Di samping kesadaran umum terhadap perkara-perkara di atas, di tengah-tengah umat juga harus tumbuh kesadaran tentang Hizbut Tahrir dan keikhlasannya dalam membebaskan umat dari dominasi sistem kufur, dan kesiapannya untuk menyongsong perkara yang amat besar ini.

Realitas Umat Islam; Mereka Siap Menerima Perkara Besar Ini Atau Belum Siap

Keadaan umum umat Islam sekarang menunjukkan bahwa mereka berhasil menyiapkan atmosfer nushrah dan istilam alhukm. Hal ini bisa dilihat dari realitas berikut ini:

1. Opini umum untuk membela Islam.

Di banyak negara, opini umum untuk membela Islam, dan keinginan untuk hidup di bawah naungan Daulah Islamiyyah telah terbentuk secara masif pada mayoritas penduduknya. Keadaan seperti ini bisa dijumpai di Aljazair, Turki, Sudan, Mesir, Yordan, Pakistan, Malaysia, Indonesia, Banglades, Maroko, Palestina, Yaman, Libya, Tunisia, Suriah dan lain-lain. Masifnya opini umum di negerinegeri ini bisa dilihat dari hasil pemilihan umum serta masirahmasirah yang dilakukan oleh kelompok-kelompok Islam yang secara terbuka menyerukan syi'arsyi'ar Islam.

2. Terjadinya proses pembentukan opini umum untuk membela Hizb di beberapa negeri Islam.

Pembentukan opini umum untuk membela Hizb, dari sisi penerimaan umat terhadap pemikiran-pemikiran penting Hizb, seperti pemikiran Khilafah Islamiyyah, dan pandanganpandangan politiknya, telah berhasil cukup baik. Di beberapa negara, seperti Indonesia, Turki, Sudan, dan Pakistan, Hizb telah berhasil menghimpun umat, sehingga mereka rela membantu dan membela Hizb dalam melawan sepak terjang kaum kafir.Sayangnya, opini umum untuk membela Hizb masih harus menghadapi sejumlah 
halangan, sehingga tidak memungkinkan bagi Hizb untuk memimpin umat dan meraih kekuasaan dari mereka. Faktorfaktor penghalangnya adalah sebagai berikut;

(1) Pendustaan opini yang dilakukan oleh para penguasa terhadap Hizb, semacam

dikembangkannya opini bahwa Hizb adalah gerakan teroris, menyimpang, sesat, dan lain sebagainya.

(2) Penyesatan opini yang dilakukan oleh ulamaulama yang menjadi kaki tangan penguasa fasik dan zalim untuk menyerang Hizb, keikhlasannya serta pandanganpandangannya. Misalnya, mereka mengembangkan pemikiran bolehnya banyak pemimpin di negeri-negeri Islam, utopisnya Khilafah, keharusan menerima demokrasi, dan lain sebagainya,

(3) Adanya partai, ormas, dan lembaga swadaya masyarakat yang memiliki hubungan dengan penguasa maupun negara-negara imperialis yang terus menikam Hizb dan keikhlasannya.

Tetapi, upaya pendustaan dan penyesatan opini, maupun tikamantikaman yang dilakukan oleh kelompok-kelompok lain, sedikit demi sedikit mulai tersingkap. Akibatnya, umat semakin yakin akan kepemimpinan dan keikhlasahan Hizb dalam memperjuangkan hakhak umat. Opini umum untuk membela Islam, Hizb dan aktivisnya semakin hari semakin menguat, dan tumbuh pesat hampir di seluruh negeri-negeri Islam.

3. Strategi thalabun nushrah era sekarang

Aktivitas thalabun nushrah untuk meraih kekuasaan umat hanya bisa sempurna ketika opini umum yang lahir dari kesadaran umum untuk membela Islam dan Hizb telah lahir di tengah-tengah umat secara sempurna pada sebuah negeri yang hendak ditegakkan Daulah Islamiyyah di dalamnya. Namun, musuh-musuh dakwah, terutama kaum kafir imperialis dan para penguasa antek berusaha menghalang-halangi terwujudnya opini umum tersebut dengan cara menyerang pandangan-pandangan Hizb, keikhlasannya, serta metode perubahan yang ditempuh oleh Hizb. Ini ditujukan agar opini umumtentang Islam dan Hizb yang lahir dari kesadaran untuk membela Islam dan Hizb tidak tumbuh di tengah-tengah masyarakat.

Atas dasar itu, tugas utama dari Hizb adalah menjaga konsistensi dirinya untuk berpegang teguh di atas pemikiran dan pandangannya yang shahih, serta menjaga keikhlasan perjuangannya dari semua bentuk tipu daya dunia.

Dari sinilah dapat disimpulkan bahwa tugas utama Hizb pada masa sekarang, sebagai langkah konkret untuk menyiapkan suasana nushrah 
adalah berpeguh teguh kepada mabda' Islam tanpa pernah bergeser seujung rambut pun, dan menjaga keikhlasan perjuangannya dari seluruh bentuk penyimpangan dan tendensi-tendensi dunia.

Adapun aktivitas yang harus dilakukan oleh Hizb untuk mewujudkan perkara-perkara di atas adalah sebagai berikut:

Pertama, memelihara keikhlasan dan ketaqwaannya kepada Allah SWT dengan cara memupuk ketaatan dan mendekatkan diri kepadaNya pada seluruh aspeknya. Pasalnya, Allah tidak akan menyerahkan amanah agama ini kecuali kepada orangorang yang bertaqwa, ikhlash, dan dekat denganNya. (QS, An-Nur 55)

Kedua, sabar untuk selalu berkorban dan melaksanakan tugastugas dakwah dengan sungguhsungguh. Kaum kafir imperialis berusaha untuk menghancurkan kekuatan Hizb melalui kaki tangan mereka dari kalangan penguasapenguasa Muslim. Untuk itu, pada saat Hizb berhasil merengkuh dukungan umat secara massif melawan sistem kufur dan penjaganya, seperti yang terjadi di Uzbekistan, para penguasa segera mendeklarasikan perang melawan aktivis dan pendukung Hizb. Dalam kondisi semacam ini, aktivis-aktivis Hizb tidak boleh surut ke belakang, atau mengendorkan perjuangannya.

Sebaliknya, mereka harus mencurahkan segenap tenaga dan pengorbanannya untuk berpegang teguh kepada perjuangan Hizb yang lurus dan suci.
Ketiga, meningkatkan tenaga dan aktivitas yang ditujukan untuk "membentengi" umat. Pasalnya, musuh-musuh Islam berusaha terus menerus untuk meletakkan di hadapan umat berbagai macam pendustaan, penyesatan, dan makar terhadap Hizb, pemikiran, dan pandangan-pandangannya. Upaya itu dilakukan untuk menjauhkan umat dari Hizb dan aktivisnya. Oleh karena itu, aktivis Hizb harus meningkatkan tenaga dan aktivitas yang ditujukan untuk membentengi dari semua bentuk penyesatan, pendustaan, dan makar terhadap Hizb dan aktivisnya; sekaligus untuk menghancurkan dinding penyesatan yang diletakkan di hadapan umat.

Keempat, para aktivis Hizb harus menonjolkan karakter dirinya sebagai seorang Mukmin yang selalu ikhlash dalam beramal dan senantiasa mengikatkan diri dengan hukum syariat, serta tekun dalam ibadah dan mendekatkan diri kepada Allah SWT. Seorang pengemban dakwah harus rajin membaca alQuran dan mengajak masyarakat untuk membaca al-Quran, hadir dalam sholat berjama'ah di masjid, mendirikan sholat malam, berinfaq, dan lain sebagainya.Aktivitasaktivitas inilah yang akan mendekatkan Hizb dan aktivisnya kepada nushrah Allah (pertolongan Allah) sehingga terwujudnya khilafah Islam. Dari pembahasan ini peneliti mengambil kesimpulan bahwa strategi dakwah dan politik yang dilakukan oleh hizbut tahrir lebih banyak ditekankan kepada pendekatan yang bersifat kultural meskipun dalam hal-hal tertentu 
menggunakan pendekatan yang sifatnya struktural.

\section{KESIMPULAN}

Dalam upaya meneladani rasulullah saw. pada perjuangan menegakkan khilafah di masa modern ini, maka langkah pertama yang harus ditempuh adalah membentuk kelompok atau partai politik Ideologis yang memiliki pemahaman yang jelas terhadap ide-ide Islam secara menyeluruh dan memahami metode perjuangan Rasulullah saw. secara detail. Mau tidak mau parpol tersebut harus melakukan kajian mendalam terhadap tsaqofah islam, baik itu Al Quran, Tafsir, Sunnah, Fiqh, maupun Sirah Nabi SAW. Kelompok itu juga harus memiliki pengurus dan kaderkader yang memiliki keahlian dalam menggerakkan partai tersebut serta memiliki kesadaran yang cukup terhadap metode yang benar bagaimana mengikat para anggotanya dengan ide dan metode dakwahnya. Parpol tersebut juga harus memiliki kesadaran politik terhadap dunia internasional.

Parpol ideologis yang komit dengan Islam itu harus melakukan proses penyadaran kepada umat secara keseluruhan, khsusnya kepada para ulama, intelektual, tokoh-tokoh gerakan islam, pimpinan parpol dan ormas Islam, para hartawan muslim, para pemuda dan mahasiswa islam, dan kelompokkelompok potensial lainnya dalam diri umat ini. Parpol itu harus membina umat dengan Islam sebagai agama dan ideologi yang mengatur seluruh aspek kehidupan, memberi kesadaran politik sebagai pengaturan urusan umat yang harus dilakukan oleh negara dan dikontrol oleh umat melalui proses amar makmur nahi mungkar, dan memberikan persepsi tentang perjuangan partai politik ideologis yang berjuang menegakkan Islam secara damai melalui pergulatan pemikiran dan perjuangan politik.

Apabila terdapat kesadaran politik umat, partai tersebut bisa menguatkan tubuhnya dengan berbagai aktivitas pemikiran dan politik dan berusaha melebur umat dengan ide-ide, hokum-hukum, dan pendapat-pendapat islami yang diadopsinya. Lalu berusaha menggapai kepemimpinan umat dan setiap anggotanya menjadi rujukan umat dalam masalah Islam dan perkembangan politik dunia.

Ringkasnya, hal yang harus dilakukan oleh HTI untuk menegakkan khilafah adalah : Melalui jalan dakwah yang ditempuh dengan mengikuti thariqah dakwah Rasulullah, yaitu:

- Dimulai dengan pembentukan kader yang bersyakhshiyyah Islamiyyah, melalui pembinaan intensif (halqah murakkazah) dengan materi dan metode tertentu

- Pembinaan umat (tatsqif jamaiy) untuk terbentuknya pendapat masyarakat (alwa'yu al-amy) tentang Islam

- Pembentukan kekuatan politik melalui pembesaran tubuh jamaah (tanmiyatu jizmi al-hizb) agar kegiatan pengkaderan dan pembinaan umum dapat dilakukan 
dengan lebih intensif, hingga terbentuk kekuatan politik (alquwwatu al-siyasiya)

- Penegakan syariah dan khilafah memerlukan kekuatan politik. Kekuatan politik adalah kekuatan umat yang memilliki kesadaran politik Islam (al-wa'yu alsiyasiy al-islamy)), yakni kesadaran bahwa kehidupan bermasyarakat dan bernegara harus diatur dengan syariah Islam. Maka harus ada upaya penyadaran politik islamy masyarakat terus menerus, yang dilakukan oleh kader. Makin banyak kader, makin cepat kesadaran terbentuk sehingga kekuatan politik juga makin cepat terwujud

- Massa umat yang memiliki kesadaran politik menuntut perubahan ke arah Islam

- Di dukung oleh ahlquwwah (polisi, militer, politisi, orang kaya, tokoh masyarakat dan sebagainya) yang melalui pendekatan intensif, setuju mendukung perjuangan syariat dan khilafah. Kekuatan politik yang didukung oleh berbagai pihak semacam ini tidak akan terbendung.

- Rakyat menuntut tegaknya sistem (syariah) dan kekuasaan khilafah atau penyatuan ke dalam khilafah Islam.

\section{DAFTAR PUSTAKA}

Abdul Qadim Zallum, Sistem Pemerintahan Islam, (Bangil : Al-Izzah, 2002), hal. 93-95.

Abdullah at-Tharablusi, 2000 Perubahan Mendasar Pemikiran Sayyid Qutub, terj. M. Maghfur Wachid, Surabaya: Ibadah.Net,

al-Ghazali Imam, Al-Mustashfa, Juz I, Mesir: Al-Matba'ah alTijariyah al-Kubra, 1937

Ali Ridha Adnan al-Nahwi, Al-Syura La al-Dimukratiyah, Kairo: Dar al-Shahwah li al-nasyr, 1985

Al-Mawardi, $\quad$ Al-Ahkam assulthaniyyah, Al-Qahirah: Dar Al-Hadits, 2006

al-QardawiYusuf, Fiqh Daulah dalam Perspektif Al-Qur'an dan Sunnah, terj, Suhardi, Jakarta: Raja Grafindo, 1994

An-Nabhani Taqiyuddin, AsySyakhsiyyah Al-Islamiyyah, jilid I, Beirut: Dar al-Ummah, 1994

An-nabhani Taqiyuddin, Nidzam alHukm fil Islam, Beirut; Dar alUmmah, 1994

Anonim, Mengenal Hizbut Tahrir dan strategi Dakwah Hizbut Tahrir, Terj. cet IV, Bogor: Pustaka Thariqul Izzah, 2010

ArcherClive, International Organization. London. Allen \& Unwin Ltd, 1983

As'Ad Said Ali, Ideologi Gerakan Pasca-Reformasi: Gerakan Sosial Politik Dalam Tinjauan Ideologis, Jakarta:LP3ES, 2012

dalam Jurnal Islamica, Vol. 6, No. 1, September 2011, h. 1-2. 
Endang Turmudzi dan Riza Sihabudin, (ed), Islam dan Radikalisme di Indonesia, Jakarta: LIPI Press, 2006

Esposito.John L, (ed.), The Oxford Encyclopedia of The Modern Islamic World, New York: Oxford University Press, 1995

Fathiy Syamsuddin Ramadhan A Nawiy, panduan Lurus Memahami Khilafah Islamiyyah Menurut Kitab Kuning, Jakarta: Wadi Press, 2013

Hafidz Abdurrahman, "Hizbut Tahrir Masuk Parlemen Mengapa Tidak?" dalam Majalah Hidayatullah, Surabaya: April 2005

HamidTijaniAbd.Qadir, Pemikiran Politik Dalam Al-Quran, Jakarta: Gema insane Press, 2001

Hartleb, Florian, 2012. "European Project in Danger? Understanding Precisely the Phenomena 'Eurosceptism, Populism, and Extremism' in Times of Crisis", Canadian Center of Science and Education, Vol. 4, No. 5, pp. 45-63.

Hasan Abul, Muslim, Shahih Muslim, (Semarang: Toha Putra, t.th.)

Hizbut Tahrir, Mengenal Hizbut Tahrir dan Strategi Dakwah Hizbut tahrir, Bogor: Pustaka Thariqul Izzah, Cet. III, 2009

Hizbut Tahrir, Mengenal Hizbut Tahrir Partai Islam Ideologis, terj. Abu Afif dan Nur khalis, Bogor: Pustaka Thariqul Izzah, 2000
Hizbut Tahrir, Strategi Dakwah Hizbut Tahrir, terj. Abu Fuad dan Abu Raihan, Bogor: Pustaka Thariqul Izzah, 2000

Hizbut-Tahrir Indonesia, Partai Politik dalam Islam, Jakarta: HTI Press.2008

Huwaid Fahmi, Li al-Islam wa alDimukratiyah, Kairo: Markaz al-Ahram li al-Thiba'ah wa alNasyr, 1993

I.J. Rosenthal, Islam in the Modern National State, (Cambridge: University Press, 1965)

Ibnu Khaldun, Mukaddimah, terj, Masturi Ilham, dkk, Jakarta: Pustaka Al-Kautsar, 2001

Ibnu Khaldun, Mukaddimah, terj. Jakarta: Pustaka Alkautsar, 2011

Ibnu Taimiyah, Majmu' Fatawa, Tahqiq: Anwar AIBaz (Dar ElWafa, 2005M/1426) Cet. III

Masdar Hilmy, "Akar-Akar Transnasionalisme Islam Hizbut Tahrir Indonesia",

Milton-Edwards, Beverly, 1996. Islamic Politics in Palestine. London and New York: Tauris.

Mohamad Rafiuddin, 2015, "Mengenal Hizbut Tahrir (Studi Analisis Ideologi Hizbut Tahrir vis a vis NU)". Islamuna. Vol 2, No 1 (2015) (29-55)

Mohammaddin, 2016,"Gerakan Dakwah Hizbut Tahrir Indonesia", JIA, vol. 17, no. 01, (47 - 62)

Muhammad Din Syamsuddin, Islam dan Politik Era Orde baru, Jakarta: Logos, 2001 
Hasanuddin, Edi Sabara Manik; Strategi Politik Hizbut Tahrir Dalam Menegakkan Khilafah Islam Di Indonesia

Nilda Hayati, 2017 "Konsep Khilafah Islamiyyah Hizbut Tahrir Indonesia, Kajian Living alQur'an perspektif Komunikasi. Epistemé, Vol. 12, No. 1, (169-200)

Rais Dhiauddin, Teori Politik Islam, Jakarta: Gema Insani Press, 2001

Rodhi Muhammad Muhsin, Tsaqofah Dan Metode Hizbut Tahrir Dalam Mendirikan Negara Khilafah Islamiyah, Jakarta: Al-Izzah , 2008

Rosenthall.J., Islam in the Modern National State, Cambridge: University Press, 1965

Syamsuddin Ramadhan An-Nawiy, Panduan lurus memahami Khilafah Islamiyah, menurut Kitab kuning, Jakarta:WadiPress,2013

Whine, Michael, 2006. "Is Hizb utTahrir Changing Strategy or Tactics?", Center for Eurasian Policy Occasional Research Paper, Series. 1, No. 1.

Zainul Kamal, dkk., Islam Negara dan Civil Society ;Gerakan dan pemikiran Islam Kontemporer, Jakarta:

Paramadina, 2005 